Atmos. Chem. Phys., 17, 10163-10193, 2017

https://doi.org/10.5194/acp-17-10163-2017

(c) Author(s) 2017. This work is distributed under

the Creative Commons Attribution 3.0 License.

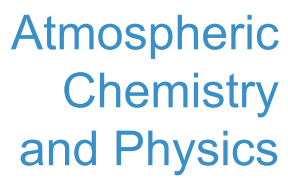

(c) (P)

\title{
Seasonal provenance changes in present-day Saharan dust collected in and off Mauritania
}

\author{
Carmen A. Friese ${ }^{1}$, Johannes A. van Hateren ${ }^{2, a}$, Christoph Vogt ${ }^{1,3}$, Gerhard Fischer ${ }^{1}$, and Jan-Berend W. Stuut ${ }^{1,2}$ \\ ${ }^{1}$ University of Bremen, Marum-Center of Marine Environmental Sciences, 28359 Bremen, Germany \\ ${ }^{2}$ NIOZ-Royal Netherlands Institute for Sea Research, Department of Ocean Systems, and Utrecht University, 1790 AB, \\ Den Burg Texel, the Netherlands \\ ${ }^{3}$ ZEKAM, Crystallography, Geosciences, University of Bremen, 28359 Bremen, Germany \\ anow at: Vrije Universiteit Amsterdam, Faculty of Earth Sciences, 1081 HV Amsterdam, the Netherlands
}

Correspondence to: Carmen A. Friese (cfriese@marum.de, cfriese@ uni-bremen.de)

Received: 9 February 2017 - Discussion started: 16 February 2017

Revised: 27 June 2017 - Accepted: 3 July 2017 - Published: 30 August 2017

\begin{abstract}
Saharan dust has a crucial influence on the earth climate system and its emission, transport and deposition are intimately related to, e.g., wind speed, precipitation, temperature and vegetation cover. The alteration in the physical and chemical properties of Saharan dust due to environmental changes is often used to reconstruct the climate of the past. However, to better interpret possible climate changes the dust source regions need to be known. By analysing the mineralogical composition of transported or deposited dust, potential dust source areas can be inferred. Summer dust transport off northwest Africa occurs in the Saharan air layer (SAL). In continental dust source areas, dust is also transported in the SAL; however, the predominant dust input occurs from nearby dust sources with the low-level trade winds. Hence, the source regions and related mineralogical tracers differ with season and sampling location. To test this, dust collected in traps onshore and in oceanic sediment traps off Mauritania during 2013 to 2015 was analysed. Meteorological data, particle-size distributions, back-trajectory and mineralogical analyses were compared to derive the dust provenance and dispersal. For the onshore dust samples, the source regions varied according to the seasonal changes in trade-wind direction. Gibbsite and dolomite indicated a Western Saharan and local source during summer, while chlorite, serpentine and rutile indicated a source in Mauritania and Mali during winter. In contrast, for the samples that were collected offshore, dust sources varied according to the seasonal change in the dust transporting air layer. In summer, dust was transported in the SAL from Mauritania, Mali and Libya as in-
\end{abstract}

dicated by ferroglaucophane and zeolite. In winter, dust was transported with the trades from Western Sahara as indicated by, e.g., fluellite.

\section{Introduction}

Mineral dust influences global climate through many feedback mechanisms and is in turn influenced by variations in environmental parameters. The emission, transport and deposition of mineral dust reacts sensitively to parameters of climate change like rainfall, wind, temperature and vegetation cover (Knippertz and Stuut, 2014). In turn, the emission, transport and deposition of mineral dust have an impact on the atmospheric energy balance (Haywood and Boucher, 2000), precipitation distribution and amplitude (Yoshioka et al., 2007), sea surface temperatures (Lau and Kim, 2007), and the oceanic carbon pump (Martin et al., 1991; Martin, 1990; Jickells et al., 2005; Iversen et al., 2010; Iversen and Robert, 2015; Ploug et al., 2008a). The sensitivity of mineral dust to environmental parameters is used to reconstruct the climate of the past (Rea, 1994; Tjallingii et al., 2008; Mulitza et al., 2010; Diester-Haass and Chamley, 1978; Holz et al., 2007; Stein, 1985). For instance, the particle size of mineral dust in ocean sediment records varies according to the paleo-frequency of dust storm and rainfall events (e.g. Friese et al., 2016). Further, the mineralogical composition of mineral dust in sediment core records can be used as a 
qualitative proxy for paleo-dust source activity (Scheuvens et al., 2013).

Every year, about $2000 \mathrm{Mt}$ dust are emitted from source areas around the world, of which $75 \%$ are deposited on land and $25 \%$ into the oceans (Shao et al., 2011). The Sahara is the world's largest source of mineral aerosols with an annual dust transport of $\sim 180 \mathrm{Mt}$ westwards towards the North Atlantic (Yu et al., 2015). About $140 \mathrm{Mt}$ is actually deposited into the North Atlantic Ocean (Yu et al., 2015). Therefore, Saharan mineral dust constitutes an essential component of the global climate system. The source regions of Saharan dust have been studied frequently by analysing the mineralogical composition of dust collected at continental sites (e.g. Skonieczny et al., 2013, 2011; Schütz and Sebert, 1987; Kandler et al., 2009; Khiri et al., 2004), during aircraft flights (e.g. Formenti et al., 2008), on research ships (Chester et al., 1971, 1972; Stuut et al., 2005; Aston et al., 1973; Chester and Johnson, 1971a, b) and with gravity cores off NW Africa (Biscaye, 1964, 1965; Lange, 1982; Rateev et al., 1969; Griffin et al., 1968; Diester-Haass and Chamley, 1978; Meyer et al., 2013). Continental dust studies in northern Morocco revealed that dust is produced predominantly locally (Khiri et al., 2004; Kandler et al., 2009). For instance, a high percentage of quartz and feldspar and a low amount of micas in the dust samples were interpreted as representing mostly local dust sources and the availability of calcite sources from proximal coastal dunes in Morocco (Khiri et al., 2004). Further, also in Morocco, dust was sampled in Tinfou at a height of $4 \mathrm{~m}$ during the SAMUM 2006 field campaign. These samples were analysed for their physical and chemical properties. The particle size correlated to local surface wind speed suggesting the contribution of local dust (Kandler et al., 2009). In contrast, in coastal Senegal, dust is sourced from the Sahel during winter as shown by low illite / kaolinite (I / K) ratios and lower palygorskite contents as opposed to the summer samples, which were suggested to originate from the Sahara (Skonieczny et al., 2013). Further, the I / K ratio in dust sampled on the Cape Verde Islands showed that dust was derived from strongly varying sources: northwestern Sahara, central and southern Sahara, and the Sahel (Caquineau et al., 2002). The results of the above-mentioned studies imply that dust collected on land is predominantly of local provenance, while the sources of dust sampled off NW Africa are of regional and long-distance provenance. As a result, a large seasonal difference can be expected in the composition of the marine climate archives, related to the different dominating transport mechanisms of dust in summer and winter (Friese et al., 2016).

To test this, we compared the mineralogical composition, the fluxes and the particle size of Saharan dust sampled from 2013 to 2015 in Iwik (Mauritania) in on-land dust traps with Saharan dust sampled from 2013 to 2015 off Cap Blanc (Mauritania) in submarine sediment traps and with the scientific dust-collecting buoy "Carmen". By comparing these data with meteorological data, back trajectories, the African lithology and satellite images, we aim to address the following questions:

- What is the seasonal variability in the particle size of mineral dust deposited on land? How does the variability relate to meteorological parameters (wind speed, precipitation)?

- What are the source regions of dust trapped on land versus dust trapped in the ocean?

- Can we identify characteristic minerals that constitute a tracer for certain source areas?

\subsection{Study sites and North African dust sources}

In Fig. 1 the location of the study sites and North African dust sources are displayed. The dust-collecting buoy Carmen $\left(\sim 21^{\circ} 15^{\prime} \mathrm{N}, \sim 20^{\circ} 56^{\prime} \mathrm{W}\right)$ and the sediment trap mooring site $\mathrm{CB}\left(\sim 21^{\circ} 16^{\prime} \mathrm{N}, \sim 20^{\circ} 48^{\prime} \mathrm{W}\right)$ are virtually at the same position $\sim 200$ nautical miles off Cap Blanc. The sediment trap station $\mathrm{CBi}\left(\sim 20^{\circ} 45^{\prime} \mathrm{N}, \sim 18^{\circ} 42^{\prime} \mathrm{W}\right)$ is located $\sim 80$ nautical miles off Cap Blanc. The continental dust collector Iwik $\left(\sim 19^{\circ} 53^{\prime} \mathrm{N}, \sim 16^{\circ} 18^{\prime} \mathrm{W}\right)$ and the meteorological station Arkeiss $\left(\sim 20^{\circ} 7^{\prime} \mathrm{N}, \sim 16^{\circ} 15^{\prime} \mathrm{W}\right)$ are located in a major potential dust source area (PSA 2) in the Parc National de Banc d'Arguin (PNBA) near Iwik and near Arkeiss in Mauritania. A further meteorological station is positioned in the PSA 2 in Nouâdhibou $\left(\sim 20^{\circ} 55^{\prime} \mathrm{N}, \sim 17^{\circ} 1^{\prime} \mathrm{W}\right)$ in Western Sahara.

The major PSA of northern African dust are summarized in a review by Scheuvens et al. (2013). Predominant dust transport towards western Africa and off the Atlantic Ocean occurs from the foothills of the Atlas mountains, Western Sahara and western Mauritania (PSA 2), southern Algeria and northern Mali (PSA 3), and western Chad, including the Bodélé depression (PSA 5) (Scheuvens et al., 2013). In contrast, dust sourced from Tunisia and northern Algeria (PSA 1) is transported predominantly to the western Mediterranean and western Europe (Stuut et al., 2009). Central Libya (PSA 4) is the most important region for dust transport to the eastern Mediterranean (Scheuvens et al., 2013).

\subsection{Geological characterization of dust-producing areas}

In the following, the lithology of the geological provinces that underlie the major PSAs is outlined (Fig. 1).

The PSA 1 is underlain by the eastern Atlas chain and the northern Grand Erg/Ahnet and Ghadames basins. The outcrops in the Atlas uplift are composed of, e.g., limestones, sandstones and evaporites (Piqué, 2001). The thick strata overlying the northern Ahnet and Ghadames basins consist of, e.g., sandstones and mudstones (Selley, 1997b).

The PSA 2 is underlain by the Reguibat Shield, the Mauritanides and the Senegal-Mauritania, Aaiún-Tarfaya, Tindouf and Taoudeni basins. The western part of the Reguibat 


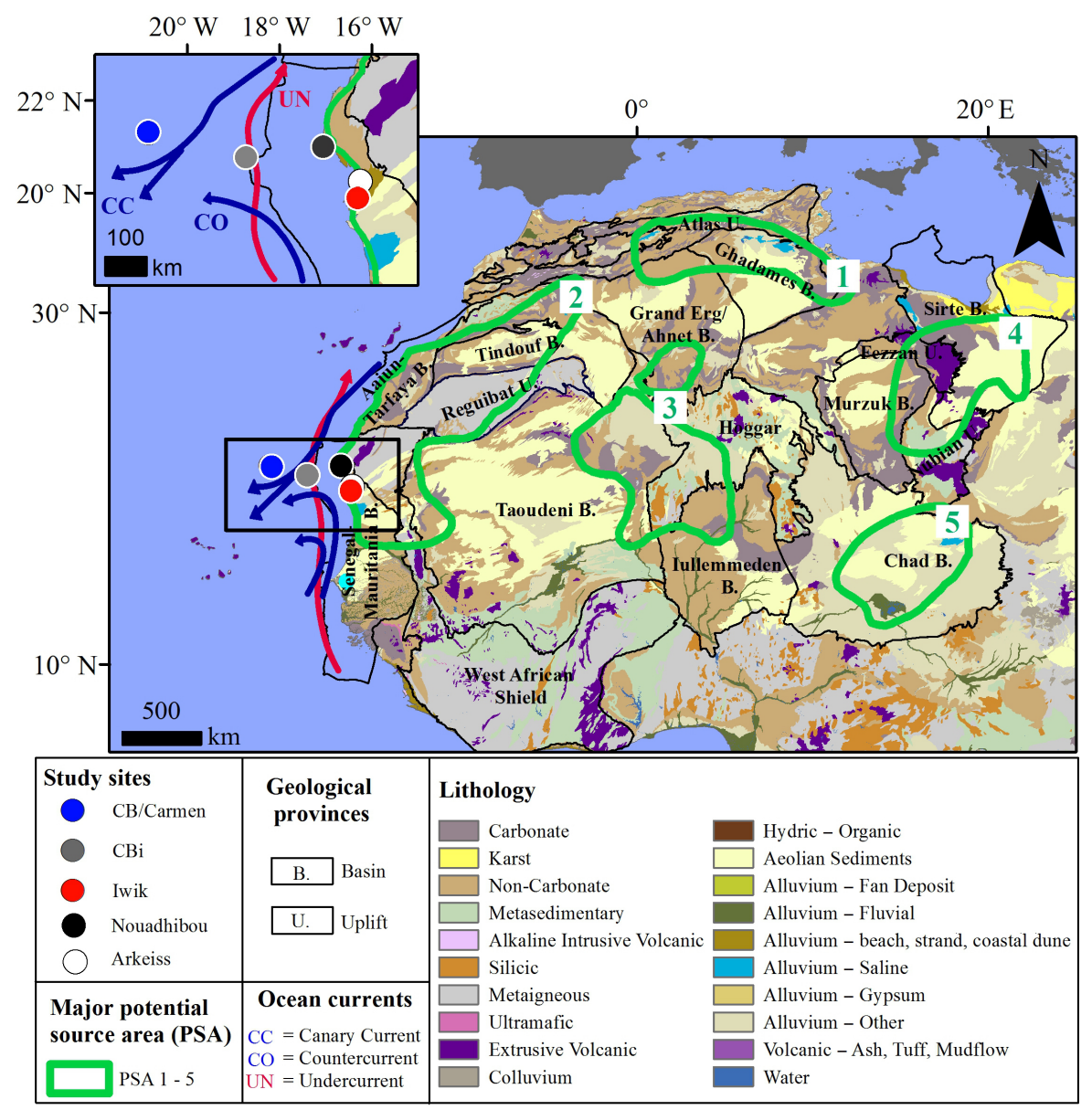

Figure 1. Map of the study sites under investigation: the scientific buoy Carmen as well as the sediment trap moorings CB and CBi off Cap Blanc, the MWAC (modified Wilson and Cooke) dust collector onshore near Iwik, and the surface station near Nouâdhibou and Arkeiss (shapefile of the surface lithology and the geological provinces: downloaded from the USGS website https://rmgsc.cr.usgs.gov/outgoing/ ecosystems/AfricaData/ and http://certmapper.cr.usgs.gov/geoportal/catalog/main/home.page; major potential dust source areas: redrawn from Scheuvens et al. (2013); ocean currents: redrawn from Mittelstaedt, 1991).

Shield is dominated by granitic rocks, while the eastern part is dominated by metamorphic and granitic rocks (Schofield et al., 2006, and references therein). West of the Reguibat Shield, the Mauritanides consist of a metamorphic belt and ophiolite (Villeneuve, 2005). West of the Taoudeni Basin, the Mauritanides are characterized by granites, quartzites and strongly metamorphosed rocks (Villeneuve, 2005). While the Aaiún-Tarfaya Basin features outcrops with dolomites and limestones, the Senegal-Mauritania Basin is characterized by very few carbonate deposits (Bosse and Gwosdz, 1996). The Tindouf Basin is characterized by mainly sandy deposits (Selley, 1997c, b). The local soils surrounding the dust collector site Iwik are composed of sandy deposits often rich in fossil shells and partly cemented by lime (Einsele et al., 1974).

The PSA 3 is underlain by the western Hoggar and parts of the Ahnet, Taoudeni and Iullemmeden basins. The Pharusian belt located in the western Hoggar is characterized by
Eburnean granulites, gneiss, greywackes and magmatic rocks (Boullier et al., 1991). In the southern Ahnet Basin sandstone strata crop out. On the eastern edge of the Taoudeni Basin outcropping sediments are characterized by conglomerates, sandstones and limestones (Bertrand-Sarfati et al., 1991). The outcrops of the Iullemmeden Basin are composed of, e.g., sandstones, carbonaceous shale, laterites and massive clays (Kogbe, 1973).

The PSA 4 is underlain by parts of the Fezzan and Nubian uplifts and the Sirte and Murzuq basins. The eastern Fezzan uplift consists of ocean island basalts (Cvetković et al., 2010; Abdel-Karim et al., 2013), while sediments outcropping in the northern Nubian uplift is composed of, e.g., sandstones, limestones and gypsiferous horizons (El Makkrouf, 1988). The southern Sirte Basin is covered by sands, gravel and sand seas (Selley, 1997a). Outcrops of the eastern Murzuq Basin are composed of marine limestones and alluvial sandstones (Selley, 1997b, c). 
The PSA 5 is underlain by the Chad Basin. During the Holocene, the Chad Basin was filled with fine-grained particles from the drainage of the Tibesti mountains to the north (Prospero et al., 2002). Hence, the sediments that outcrop in the central Chad Basin are characterized by fluvial and alluvial sediments such as laminated diatomites, pelites and coastal sand ridges (Schuster et al., 2009).

\subsection{Atmospheric setting}

Saharan dust emission, transport and deposition are related to seasonal variations in atmospheric circulation (Knippertz and Todd, 2012). The intertropical convergence zone (ITCZ) shifts meridionally from $\sim 12^{\circ} \mathrm{N}$ during boreal winter to $\sim 21^{\circ} \mathrm{N}$ during boreal summer, resulting in a seasonal change in rainfall and winds over the African continent (Nicholson, 2009).

During summer, continental rainfall is most intense and the rain belt is positioned near $\sim 10^{\circ} \mathrm{N}$ with smaller amounts of rainfall near $\sim 21^{\circ} \mathrm{N}$. Dust emission is driven by low level jets, "haboobs", African easterly waves (AEWs) and high surface winds associated with the Saharan heat low (Knippertz and Todd, 2012). Low-level $\mathrm{N}$ trade winds blow and transport dust in coastal Mauritania year-round (National Geospatial-Intelligence Agency, 2006). Saharan dust is transported on- and offshore within the Saharan air layer (SAL) at an altitude of about $3 \mathrm{~km}$ (Diaz et al., 1976; Carlson and Prospero, 1972; Prospero and Carlson, 1972, 1970).

During winter, dust emission is driven by the breakdown of nocturnal low-level jets after sunrise, increased surges in Harmattan winds and microscale dust devils and dust plumes (Knippertz and Todd, 2012; Koch and Renno, 2005). Dust is transported within the low-level NE and E trade winds to coastal Mauritania (Dobson, 1781) and also offshore to the sediment trap mooring sites (Stuut et al., 2005).

\subsection{Oceanic setting}

The surface water circulation off Cap Blanc is influenced by the southward-flowing Canary Current (CC) and the poleward-flowing coastal countercurrent or Mauritania Current (Fig. 1). Underneath, the undercurrent is flowing poleward in water depths down to $1000 \mathrm{~m}$ (Fig. 1). The undercurrent flows along the continental slope and transports water masses originating from $\sim 5$ to $10^{\circ} \mathrm{N}$ to latitudes up to $26^{\circ} \mathrm{N}$. The poleward-flowing South Atlantic Central Water (SACW) and the southward-flowing North Atlantic Central Water (NACW) are situated below the countercurrent and meet off Cap Blanc (Mittelstaedt, 1991). The study area is positioned in a zone of permanent annual upwelling of subsurface water masses (Cropper et al., 2014). The NACW and SACW may be upwelled and mixed laterally off Cap Blanc (Meunier et al., 2012). The permanent annual upwelling of nutrient-rich subsurface waters results in high phytoplankton concentrations off Cap Blanc (Van Camp et al., 1991). As a result, the surface waters are rich in organic detritus, usually referred to as "marine snow", and faecal pellets which are produced by marine zooplankton (Iversen et al., 2010).

Individual Saharan dust particles which settle at the ocean surface hardly settle in the deep sea. Instead, fine dust particles can be transferred from the ocean surface to the deep sea by being incorporated into marine snow aggregates and faecal pellets (Ternon et al., 2010). The aggregate formation and ballasting of marine snow aggregates and faecal pellets with marine carbonate and opal as well as with Saharan dust particles results in anomalously high sinking velocities (Iversen and Robert, 2015; Fischer and Karakas, 2009; Iversen and Ploug, 2010; Iversen et al., 2010; Ploug et al., 2008b). Dustloaded particles that sink into the deeper water column are assumed to have a mean settling speed of $\sim 240 \mathrm{~m} \mathrm{~d}^{-1}$ at site CB (Fischer and Karakas, 2009).

\section{Material and methods}

In Table 1 an overview of the material and methods employed for each study site is presented. Bulk sediment samples were obtained at sites $\mathrm{CB}$ and $\mathrm{CBi}$, and dust samples were taken at sites Carmen and Iwik. All samples were analysed for particle size and dust flux with the exception of site Carmen, for which only dust particle size was analysed. Only sites CBi and Iwik were analysed for mineral assemblages, and only the samples of site Iwik were used for microscopic investigation. Meteorological sensors were available for the stations Carmen, Iwik and Arkeiss, while for site Nouâdhibou meteorological data were downloaded online. TRMM (Tropical Rainfall Measuring Mission) precipitation data were downloaded online for all sites except for site Nouâdhibou.

\subsection{Sediment traps}

Saharan dust was collected in the ocean using marine sediment traps of the type Kiel (model SMT-234/243), which are conical with an opening of $0.5 \mathrm{~m}^{2}$ (Fig. 2). The principle of particle collection is much the same as described by Van der Does et al. (2016) and Korte et al. (2017). At the top of the opening, a honeycomb grid is installed to prevent large swimmers $(>1 \mathrm{~cm})$ from entering the trap. The sediment traps were equipped with 20 sample cups which rotated according to a preprogrammed sampling interval (Fischer and Wefer, 1991). The sampling interval was chosen depending on the timing of the ship expeditions.

The sampling intervals were synchronized between the two sites. The intervals ranged from 9.5 to 26 days (Table 2). Deployment and recovery of the sediment trap samples was performed during the RV Poseidon expeditions POS445 (Fischer et al., 2013), POS464 (Fischer et al., 2014) and POS481 (Fischer et al., 2015) (Table 2). The working steps related to the trap deployment and treatment are described in Fischer and Wefer (1991). In order to prevent the outflow of water 
Table 1. Overview of the material and methods employed at each study site.

\begin{tabular}{|c|c|c|c|c|c|}
\hline Study site & Lat/long & Samples & Analysis & $\begin{array}{l}\text { Meteorological sensor } \\
\text { and data }\end{array}$ & $\begin{array}{l}\text { Downloaded meteo- } \\
\text { rological data }\end{array}$ \\
\hline Carmen & $\begin{array}{l}\sim 21^{\circ} 15^{\prime} \mathrm{N} \\
\sim 20^{\circ} 56^{\prime} \mathrm{W}\end{array}$ & 1 MWAC sample & particle size & $\begin{array}{l}\text { Vaisala WXT520: wind } \\
\text { direction and speed, pre- } \\
\text { cipitation }\end{array}$ & $\begin{array}{l}\text { TRMM 3B42: pre- } \\
\text { cipitation }\end{array}$ \\
\hline $\mathrm{CB}$ & $\begin{array}{l}\sim 21^{\circ} 16^{\prime} \mathrm{N} \\
\sim 20^{\circ} 48^{\prime} \mathrm{W}\end{array}$ & $\begin{array}{l}38 \text { sediment trap } \\
\text { samples }\end{array}$ & $\begin{array}{l}\text { lithogenic fluxes, } \\
\text { particle size }\end{array}$ & - & $\begin{array}{l}\text { TRMM 3B42: pre- } \\
\text { cipitation }\end{array}$ \\
\hline $\mathrm{CBi}$ & $\begin{array}{l}\sim 20^{\circ} 45^{\prime} \mathrm{N} \\
\sim 18^{\circ} 42^{\prime} \mathrm{W}\end{array}$ & $\begin{array}{l}38 \text { sediment trap } \\
\text { samples }\end{array}$ & $\begin{array}{l}\text { lithogenic fluxes, } \\
\text { particle size, mineral } \\
\text { assemblages }\end{array}$ & - & $\begin{array}{l}\text { TRMM 3B42: pre- } \\
\text { cipitation, } \\
\text { HYSPLIT back tra- } \\
\text { jectories }\end{array}$ \\
\hline Iwik & $\begin{array}{l}\sim 19^{\circ} 53^{\prime} \mathrm{N} \\
\sim 16^{\circ} 18^{\prime} \mathrm{W}\end{array}$ & $\begin{array}{l}24 \text { MWAC sam- } \\
\text { ples }\end{array}$ & $\begin{array}{l}\text { microscopy, dust } \\
\text { fluxes, particle size, } \\
\text { mineral assemblages }\end{array}$ & $\begin{array}{l}\text { Davis } 6250 \text { Vantage Vue: } \\
\text { wind direction and speed }\end{array}$ & $\begin{array}{l}\text { TRMM 3B42: pre- } \\
\text { cipitation, } \\
\text { HYSPLIT back tra- } \\
\text { jectories }\end{array}$ \\
\hline Nouâdhibou & $\begin{array}{l}\sim 20^{\circ} 55^{\prime} \mathrm{N} \\
\sim 17^{\circ} 1^{\prime} \mathrm{W}\end{array}$ & - & - & - & $\begin{array}{l}\text { Wind direction and } \\
\text { speed }\end{array}$ \\
\hline Arkeiss & $\begin{array}{l}\sim 20^{\circ} 7^{\prime} \mathrm{N} \\
\sim 16^{\circ} 15^{\prime} \mathrm{W}\end{array}$ & - & - & $\begin{array}{l}\text { Davis } 6250 \text { Vantage Vue: } \\
\text { precipitation }\end{array}$ & $\begin{array}{l}\text { TRMM 3B42: pre- } \\
\text { cipitation }\end{array}$ \\
\hline
\end{tabular}

Table 2. Specifications of the sediment trap samples collected during 2013-2015 chosen for flux and grain-size analysis.

\begin{tabular}{|c|c|c|c|c|c|c|c|c|c|}
\hline Trap series & $\begin{array}{l}\text { Trap } \\
\text { type }\end{array}$ & $\begin{array}{l}\text { Sampling } \\
\text { period }\end{array}$ & $\begin{array}{l}\text { Cruise } \\
\text { deployment }\end{array}$ & $\begin{array}{l}\text { Cruise } \\
\text { recovery }\end{array}$ & Position & $\begin{array}{l}\text { Trap } \\
\text { depth } \\
\text { (m) }\end{array}$ & $\begin{array}{l}\text { Water } \\
\text { depth } \\
\text { (m) }\end{array}$ & $\begin{array}{l}\text { No. of } \\
\text { samples }\end{array}$ & $\begin{array}{l}\text { Sampling } \\
\text { intervals }\end{array}$ \\
\hline $\begin{array}{l}\text { CBi } 11 \text { upper } \\
\text { (GeoB 18006-2) }\end{array}$ & $\begin{array}{l}\text { SMT } \\
243\end{array}$ & $\begin{array}{l}29 \text { Jan } 2013- \\
25 \text { Mar } 2014\end{array}$ & Pos445 & Pos464 & $\begin{array}{l}20^{\circ} 46.4^{\prime} \mathrm{N} \\
18^{\circ} 44.4^{\prime} \mathrm{W}\end{array}$ & 1406 & 2800 & 18 & $\begin{array}{l}17 \times 21 \text { days } \\
1 \times 20 \text { days }\end{array}$ \\
\hline $\begin{array}{l}\text { CBi } 12 \text { upper } \\
(\text { GeoB 19402-01) }\end{array}$ & $\begin{array}{l}\text { SMT } \\
234 \mathrm{NE}\end{array}$ & $\begin{array}{l}14 \text { Feb 2014- } \\
23 \text { Feb } 2015\end{array}$ & Pos464 & Pos 481 & $\begin{array}{l}20^{\circ} 46.4^{\prime} \mathrm{N} \\
18^{\circ} 44.5^{\prime} \mathrm{W}\end{array}$ & 1356 & 2750 & 20 & $\begin{array}{l}1 \times 12.5 \text { days, } \\
18 \times 19.5 \text { days } \\
1 \times 10.5 \text { days }\end{array}$ \\
\hline $\begin{array}{l}\text { CB } 24 \text { upper } \\
\text { (GeoB 18001-1) }\end{array}$ & $\begin{array}{l}\text { SMT } \\
234 \mathrm{NE}\end{array}$ & $\begin{array}{l}24 \text { Jan } 2013- \\
5 \text { Feb } 2014\end{array}$ & Pos445 & Pos464 & $\begin{array}{l}21^{\circ} 16.9^{\prime} \mathrm{N} \\
20^{\circ} 50.6^{\prime} \mathrm{W}\end{array}$ & 1214 & 4160 & 18 & $\begin{array}{l}1 \times 26 \text { days, } \\
16 \times 21 \text { days } \\
1 \times 15 \text { days }\end{array}$ \\
\hline $\begin{array}{l}\text { CB } 25 \text { lower } \\
\text { (GeoB 19401-1) }\end{array}$ & $\begin{array}{l}\text { SMT } \\
234 \mathrm{NE}\end{array}$ & $\begin{array}{l}7 \text { Feb 2014- } \\
21 \text { Feb } 2015\end{array}$ & Pos 464 & Pos 481 & $\begin{array}{l}21^{\circ} 17.8^{\prime} \mathrm{N} \\
20^{\circ} 47.8^{\prime} \mathrm{W}\end{array}$ & 3622 & 4160 & 20 & $\begin{array}{l}19 \times 19.5 \text { days } \\
1 \times 9.5 \text { days }\end{array}$ \\
\hline
\end{tabular}

from the cups during sampling, each sampling cup was filled with $20 \mathrm{~mL}$ of filtered $(<0.2 \mu \mathrm{m})$ seawater with a salinity of $40 \%$. To produce seawater with a salinity of $40 \%$, $100 \mathrm{~g}$ $\mathrm{NaCl}$ Suprapur was added to $1 \mathrm{~L}$ of filtered seawater. Microbial and zooplankton activity was inhibited inside the trap samples by adding $1 \mathrm{~mL}$ of a saturated solution of the biocide $\mathrm{HgCl}_{2}$ per $100 \mathrm{~mL}$ of seawater. After recovery, swimmers $<1 \mathrm{~cm}$ were removed from the samples by sieving each sample through a $1 \mathrm{~mm}$ mesh. A McLane rotary liquid splitter was used to split the $<1 \mathrm{~mm}$ fraction of each sample into five equal aliquots.

The samples of two sediment trap deployments during 2013-2015 of the sediment trap mooring stations CB and CBi were chosen for grain-size analyses (Table 2). The upper traps sampled at an average water depth of $\sim 1300 \mathrm{~m}$ and the lower trap sampled at a water depth of $\sim 3600 \mathrm{~m}$ (Table 2). Dust which settles at the ocean surface is advected by ocean currents while settling in the water column. As a result, particles that settle in an area of $\sim 40 \times 40 \mathrm{~km}^{2}$ in the ocean surface above the traps may be collected at a water depth of $\sim 1300 \mathrm{~m}$ (Friese et al., 2016). Two winter and two summer samples were chosen for X-ray diffraction (XRD) measurements (Table 3).

\subsection{Modified Wilson and Cooke samplers}

Saharan dust was collected on land near Iwik, Mauritania, with a passive dust sampler consisting of two masts ( 1 and 2) with two sets of five air sampling bottles each (A and B, Fig. 2). The dust sampling bottles are referred to as modified Wilson and Cooke (MWAC) samplers (Mendez et al., 2011; Wilson and Cooke, 1980) and consist of a closed Polyethylene bottle through which the wind can pass via two glass tubes with $8 \mathrm{~mm}$ openings. Thus, a big difference between the traps and the MWAC collectors is the much 


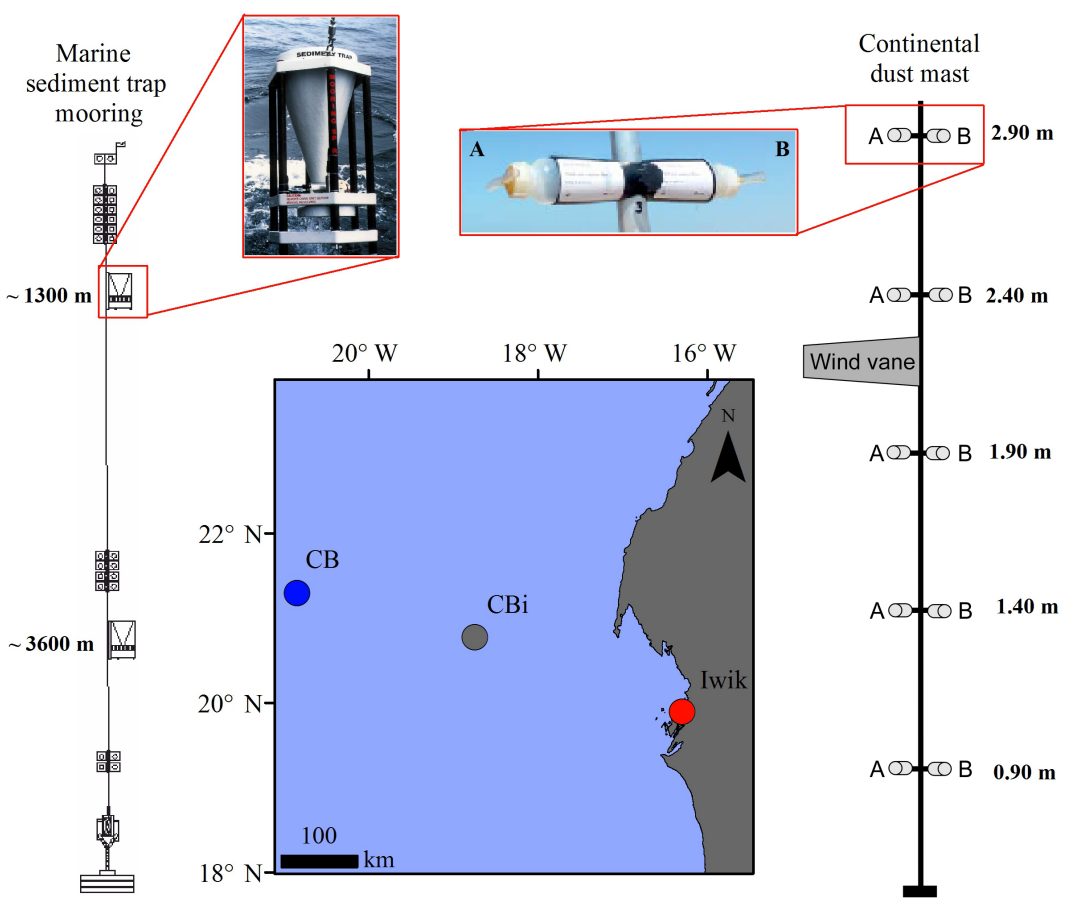

Figure 2. The marine sediment trap moorings CB and CBi off Cap Blanc and the dust masts near Iwik, Mauritania. On the left, a sketch of the sediment trap mooring (sketch of CB 24 copied from Fischer et al., 2013) together with a photograph of the trap (downloaded from www.kum-kiel.de) is displayed. On the right, a sketch of the dust mast together with a photograph of the MWAC sampling bottles is depicted.

Table 3. Sediment trap (CBi) and MWAC samples (Iwik) chosen for mineralogical investigation.

\begin{tabular}{|c|c|c|c|c|c|}
\hline Sample & Sampling period & Mast & Bottle & $\begin{array}{r}\text { Elevation/water } \\
\text { depth (m) }\end{array}$ & $\begin{array}{r}\text { Sampling } \\
\text { interval }\end{array}$ \\
\hline $\begin{array}{l}\text { CBi } 11 \text { upper no. } \\
8\end{array}$ & 25 Jun-16 Jul 2013 & - & - & 1406 & 21 days \\
\hline $\begin{array}{l}\text { CBi } 12 \text { upper no. } \\
2\end{array}$ & 26 Feb-18 Mar 2014 & - & - & 1356 & 20 days \\
\hline $\begin{array}{l}\text { CBi } 12 \text { upper no. } \\
10\end{array}$ & 1-21 Aug 2014 & - & - & 1356 & 20 days \\
\hline $\begin{array}{l}\text { CBi } 12 \text { upper no. } \\
17\end{array}$ & 16 Dec 2014-4 Jan 2015 & - & - & 1356 & 19 days \\
\hline Iwik 13-7-2-3B & 24 Jun-15 Jul 2013 & 2 & $\mathrm{~B}$ & 1.90 & 21 days \\
\hline Iwik 14-8-2-5B & 15 Aug-15 Sep 2014 & 2 & $\mathrm{~B}$ & 2.90 & 31 days \\
\hline Iwik 14-12-1-4A & 15 Dec 2014-18 Jan 2015 & 1 & A & 2.40 & 34 days \\
\hline Iwik 14-2-2-5B & 15 Feb-15 Mar 2014 & 2 & $\mathrm{~B}$ & 2.90 & 28 days \\
\hline
\end{tabular}

smaller collection area $\left(44 \mathrm{~mm}^{2}\right)$ of the MWAC collectors. The MWAC dust sampler was chosen because it is one of the most common (Zobeck et al., 2003) and most efficient dust samplers (Goossens and Offer, 2000). The sampling bottles were mounted horizontally at five different heights.

The samples collected in 2013-2015 were chosen for subsequent flux and grain-size analyses (Table 4). Saltating dust particles may be collected in the lower sampling bottles at $90 \mathrm{~cm}$. However, the aim was to analyse dust transported in suspension to enable a better comparison between the conti- nental and marine sites. Therefore, the highest sampling bottles attached to the mast at $2.90 \mathrm{~m}$ height were used for microscope, flux and grain-size analysis (Table 4). One series of bottles (series B2) on mast 2 were analysed with the microscope. The other three replicate samples (bottles A1 and B1 of mast 1, bottles A2 of mast 2) were analysed for flux and grain-size analysis. Of the three replicate samples, the sample with the highest mass was chosen for the interpretation of the flux and grain-size data because this bottle was assumed to have sampled most efficiently. Three samples mounted at a 
Table 4. Specifications of the MWAC samples collected during 2013-2015 chosen for flux and grain-size analysis.

\begin{tabular}{|c|c|c|c|c|c|c|}
\hline $\begin{array}{l}\text { Dust collector } \\
\text { series }\end{array}$ & Trap type & $\begin{array}{l}\text { Sampling } \\
\text { period }\end{array}$ & Position & Height (m) & $\begin{array}{l}\text { No. of } \\
\text { sam- } \\
\text { ples }\end{array}$ & Sampling intervals \\
\hline Iwik 13 & MWAC & $\begin{array}{l}27 \text { Jan } 2013- \\
20 \text { Jan } 2014\end{array}$ & $\begin{array}{l}19^{\circ} 53.1^{\prime} \mathrm{N} \\
16^{\circ} 17.6^{\prime} \mathrm{W}\end{array}$ & 2.90 & 11 & $\begin{array}{l}19,28,32,29,40,21,31 \\
61,31,31,35 \text { days }\end{array}$ \\
\hline Iwik 14 & MWAC & $\begin{array}{l}20 \text { Jan } 2014- \\
18 \text { Jan } 2015\end{array}$ & $\begin{array}{l}19^{\circ} 53.1^{\prime} \mathrm{N} \\
16^{\circ} 17.6^{\prime} \mathrm{W}\end{array}$ & 2.90 & 13 & $\begin{array}{l}26,28,31,30,31,30,31 \\
31,30,32,29,34 \text { days }\end{array}$ \\
\hline CB-MWAC & MWAC & $\begin{array}{l}23 \text { Aug 2014- } \\
16 \text { Nov } 2015\end{array}$ & $\begin{array}{l}21^{\circ} 15.8^{\prime} \mathrm{N} \\
20^{\circ} 56.1^{\prime} \mathrm{W}\end{array}$ & 2.00 & 1 & 450 days \\
\hline
\end{tabular}

height of $2.40 \mathrm{~m}$ of mast 2 were chosen to test the effect of the chemical pretreatments that we do to isolate the terrigenous fraction from marine sediments on the resulting grain-size distributions (Fig. 2). Two winter and two summer samples that contained enough material were chosen for XRD measurements (Table 3).

Furthermore, dust was sampled with a MWAC dust sampler mounted on the mast of buoy Carmen, at about $2 \mathrm{~m}$ above the sea surface (Stuut et al., 2015). The masts of the buoy Carmen and of the Iwik dust sampler were aligned with the ambient wind direction via a wind vane (Fig. 2). This MWAC dust sample was also analysed for grain-size distribution.

\subsection{Microscopy}

The MWAC samples chosen for microscopic investigation were analysed with a Leica M165 C microscope. Microscope pictures were taken using a Leica DFC420 camera attached to the microscope. The software Leica application suite 3.8 was used for taking the pictures.

\subsection{Dust and lithogenic fluxes}

One-fifth splits of the sediment trap samples were analysed for dust fluxes and the bulk components following the method presented in Fischer and Wefer (1991). The lithogenic flux $\left(\mathrm{mg} \mathrm{m}^{-2} \mathrm{~d}^{-1}\right)$ was estimated according to Eq. (1):

lithogenic material $=$ dust $=$ total mass - carbonate

$$
\text { - opal }-2 \times \mathrm{C}_{\text {org }} \text {. }
$$

Organic carbon was measured after the removal of carbonate with $2 \mathrm{~N} \mathrm{HCl}$ using a $\mathrm{CHN}$ analyser (HERAEUS). Total carbon was estimated by combustion without pretreatment. Carbonate was determined according to Eq. (2):

carbonate $=$ total carbon - organic carbon.

Biogenic opal was determined with a sequential leaching technique (Müller and Schneider, 1993).

The MWAC samples chosen for dust flux analyses were weighed on a Mettler-Toledo AT261 Delta Range balance with a precision of $0.0001 \mathrm{~g}$. Mean atmospheric dust concentrations were estimated as Eq. (3):

$\mathrm{DL}=\frac{\mathrm{MAR}}{(v \cdot A)} \cdot \frac{1}{\eta}$,

where DL is the mean dust concentration $\left(\mu \mathrm{g} \mathrm{m}^{-3}\right)$, MAR is the mass accumulation rate $\left(\mu \mathrm{g} \mathrm{s}^{-1}\right), v$ is the mean wind speed per sampling month $\left(\mathrm{m} \mathrm{s}^{-1}\right), A$ is the cross-sectional area of the inlet tube of the MWAC sampler $\left(\mathrm{m}^{2}\right)$ and $\eta$ is the estimated sampling efficiency of MWAC bottles. A sampling efficiency of $90 \%$ was assumed based on an efficiency study of Goossens and Offer (2000). Mean horizontal dust fluxes were calculated according to Eq. (4):

$F_{\mathrm{h}}=\frac{\mathrm{MAR}}{A} \cdot \frac{1}{\eta}$,

where $F_{\mathrm{h}}$ is the horizontal dust flux $\left(\mathrm{mg} \mathrm{m}^{-2} \mathrm{~d}^{-1}\right)$, MAR is the mass accumulation rate $\left(\mathrm{mg} \mathrm{d}^{-1}\right), A$ is the cross-sectional area of the inlet tube of the MWAC sampler $\left(\mathrm{m}^{2}\right)$ and $\eta$ is the estimated sampling efficiency of MWAC bottles.

\subsection{Particle size}

A 1/25 split of the marine sediment trap samples was analysed for particle size of the terrigenous fraction. The samples were pretreated before measurement in order to isolate this fraction (see also Filipsson et al., 2011; Friese et al., 2016; Meyer et al., 2013; Stuut, 2001, for methodology) with the following steps: (1) removal of organic matter - addition of $10 \mathrm{~mL}$ of $\mathrm{H}_{2} \mathrm{O}_{2}(35 \%)$ to the sediment sample and subsequent boiling until the reaction stops; (2) removal of calcium carbonate - addition of $10 \mathrm{~mL} \mathrm{HCl}(10 \%)$ to the sediment sample and subsequent boiling for exactly $1 \mathrm{~min}$; and (3) removal of biogenic silica - adding $6 \mathrm{~g}$ of $\mathrm{NaOH}$ pellets to the sediment sample and subsequent boiling for $10 \mathrm{~min}$. Before particle-size analysis, 10 drops of $\mathrm{Na}_{4} \mathrm{P}_{2} \mathrm{O}_{7} \cdot 10 \mathrm{H}_{2} \mathrm{O}$ were added to each sample to assure the full disaggregation of the particles. The pretreatment of the MWAC samples differed from the pretreatment of the sediment trap samples as, obviously, these samples did not contain any biogenic material originating from marine plankton. Further, the disaggregation of particles needed to be kept to a minimum to allow 
for the study of dust transport processes, the so-called "minimally dispersed" aeolian fraction (McTainsh et al., 1997). Therefore, the MWAC samples were solely pretreated with three drops of $\mathrm{Na}_{4} \mathrm{P}_{2} \mathrm{O}_{7} \cdot 10 \mathrm{H}_{2} \mathrm{O}$ before analysis. The marine sediment trap samples as well as the MWAC samples were analysed with the laser particle sizer Beckmann Coulter LS13320 at NIOZ using a micro liquid module (MLM). This instrument allows quick, accurate and precise data acquisition of large size intervals (Bloemsma et al., 2012). An analytical error of $\pm 1.26 \mu \mathrm{m}( \pm 4.00 \%)$ was considered for the measurements (Friese et al., 2016).

To investigate the comparability of the MWAC samples with the oceanic sediment trap samples, the particle-size distribution of the MWAC sample attached to buoy Carmen was compared to the averaged particle-size distributions of the upper and lower-trap series at site CB (Fig. 3a). The grainsize distribution of the MWAC sample was comparable to both sediment trap time series even though the sampling time period was different. To ensure that the pretreatment steps of the traps did not influence the terrigenous fraction itself, tests were done in which the on-land MWAC samples were exposed to the same pretreatment steps as the marine samples (Fig. 3b). One spring sample has been measured with and without a chemical pretreatment. Two autumn dust samples were obtained from the same height and mast and sampling interval, but from different bottles (A and B), and were measured with and without pretreatment. Figure $3 \mathrm{~b}$ indicates that a pretreatment of the Iwik dust samples did not alter the particle distributions of the samples significantly. Further, the particle-size distribution of dust sampled with different bottles is comparable.

\subsection{Mineral assemblages}

Two winter and two summer samples of the MWAC dust collector and the sediment trap series CBi were chosen for XRD analysis (Table 3). X-ray diffraction pattern analyses were carried out in the laboratory of the research group Crystallography (University of Bremen, Central Laboratory for Crystallography and Applied Material Sciences, ZEKAM, Dept. of Geosciences).

Due to the small amount of material in the available dust samples $(<100 \mathrm{mg})$, the preparation for the measurement was done by pipetting a demi-water-sample mixture onto glass slides. Thorough preparation commonly increases reproducibility of the results; however, the standard deviation given by Moore and Reynolds (1989) of $\pm 5 \%$ can be considered as a general guideline for mineral groups with $>20 \%$ clay fraction. In addition, the determination of well-crystallized minerals like quartz, calcite or aragonite can be done with better standard deviations (Tucker, 1988; Vogt et al., 2002). The X-ray diffraction was measured on a Philips X'Pert Pro multipurpose diffractometer equipped with a $\mathrm{Cu}$ tube $\left(k_{\alpha} 1.541,45 \mathrm{kV}, 40 \mathrm{~mA}\right)$, a fixed divergence slit of $1 / 4^{\circ}$, a secondary Ni filter and the X'Celerator de- (a)

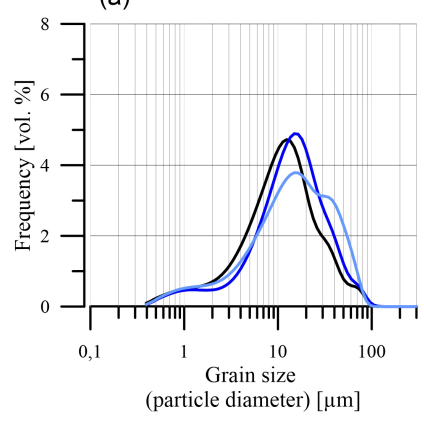

- CB-MWAC (23.08.14-16.11.15)

— CB 25 lower, averaged (07.02.14-12.02.15)
- CB 24 upper, averaged (24.01.13-05.02.14) (b)

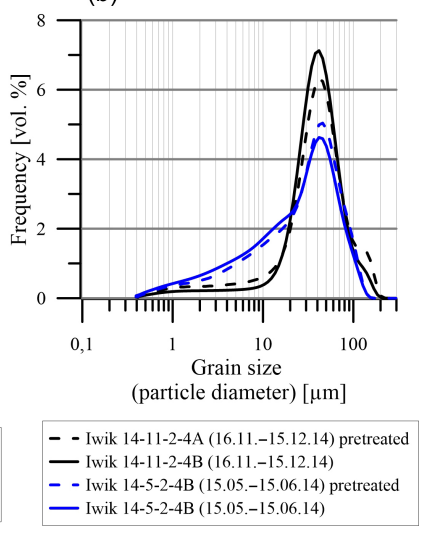

Figure 3. (a) Grain-size distributions for the station CB: dust sampled with the MWAC sampler $2 \mathrm{~m}$ a.s.l., with the upper sediment trap $1214 \mathrm{~m}$ b.s.1. and the lower trap $3622 \mathrm{~m}$ b.s.l. (b) Grain-size distributions of samples of the Iwik 14 time series which have been pretreated with $\mathrm{HCl}, \mathrm{H}_{2} \mathrm{O}_{2}$ and $\mathrm{NaOH}$ (dotted lines) and without pretreatment (lines).

tector system. The measurements were carried out as a continuous scan from 3 to $85^{\circ} 2 \theta$, with a calculated step size of $0.016^{\circ} 2 \theta$ (calculated time per step was $100 \mathrm{~s}$ ). Mineral identification was accomplished using the Philips software $\mathrm{X}^{\prime}$ Pert HighScore ${ }^{\mathrm{TM}}$, which, besides the mineral identification, can give a semi-quantitative value for each identified mineral on the basis of relative intensity ratio (RIR) values. The RIR values are calculated as the ratio of the intensity of the most intense reflex of a specific mineral phase to the intensity of the most intense reflex of pure corundum (I / Ic) referring to the "matrix-flushing method" after Chung (1974). Unfortunately RIR values are sparse for clay minerals and long-chain organic materials hampered the quantification of our samples.

\subsection{Meteorological data}

The obtained flux and size data were compared to nearby meteorological data (wind speed, wind direction and precipitation).

Wind direction, wind speed and precipitation data with a 20 min resolution were gathered for the sampling site CB $\left(21^{\circ} 17^{\prime}-21^{\circ} 12^{\prime} \mathrm{N}, 20^{\circ} 56^{\prime}-20^{\circ} 54^{\prime} \mathrm{W}\right)$ during the buoy Carmen's deployments from November 2013 to September 2015 with a Vaisala WXT520 meteorology sensor. The size of the dataset was reduced by calculating $4 \mathrm{~h}$ averages. Moreover, wind direction and wind speed data with a resolution of $5 \mathrm{~min}$ to $1 \mathrm{~h}$ were gathered during sampling at site Iwik $\left(19^{\circ} 53.1^{\prime} \mathrm{N}, 16^{\circ} 17.6^{\prime} \mathrm{W}\right)$ from January 2013 to January 2015 with a Davis 6250 Vantage Vue meteorology sensor. The size of the dataset was reduced by calculating $1 \mathrm{~h}$ averages. Further hourly precipitation data were gathered from the station Arkeiss $\left(20^{\circ} 7^{\prime} \mathrm{N},-16^{\circ} 15^{\prime} \mathrm{W}\right)$ from December 2013 to 
March 2015 with another Davis 6250 Vantage Vue meteorology sensor. Continental hourly wind direction and wind speed data were acquired online for the Nouâdhibou meteorological station $\left(20^{\circ} 55^{\prime} \mathrm{N}, 17^{\circ} 1^{\prime} \mathrm{W}\right)$ from the Cedar Lake Ventures website (https://weatherspark.com).

Local daily precipitation data (TRMM 3B 42 dataset, $0.25^{\circ}$ spatial resolution) were derived from the Giovanni online data system, developed and maintained by the NASA GES DISC (https://giovanni.gsfc.nasa.gov). Daily precipitation data were downloaded as area-averages around $\mathrm{CBi}\left(20^{\circ} 58^{\prime}-\right.$ $\left.20^{\circ} 34^{\prime} \mathrm{N}, 18^{\circ} 56-18^{\circ} 32^{\prime} \mathrm{W}\right)$, Iwik $\left(19^{\circ} 41^{\prime}-20^{\circ} 5^{\prime} \mathrm{N}, 16^{\circ} 29^{\prime}-\right.$ $\left.16^{\circ} 5^{\prime} \mathrm{W}\right), \mathrm{CB} / \mathrm{Carmen}\left(21^{\circ} 5^{\prime}-21^{\circ} 29^{\prime} \mathrm{N}, 21^{\circ} 2^{\prime}-20^{\circ} 38^{\prime} \mathrm{W}\right)$ and Arkeiss $\left(20^{\circ} 19^{\prime}-19^{\circ} 55^{\prime} \mathrm{N}, 16^{\circ} 28^{\prime}-16^{\circ} 4^{\prime} \mathrm{W}\right)$ according to the assumed catchment area of the upper trap $(\sim 40 \times$ $40 \mathrm{~km}^{2}$ ).

Maps of six-hourly mean surface wind vectors and speed (20th century reanalysis V2c dataset) were provided by the NOAA/OAR/ESRL PSD (Boulder, Colorado, USA) and downloaded from their website (http://www.esrl.noaa.gov/ $\mathrm{psd} /$ ).

\subsection{Mapping with ArcMap}

The mapping software ArcMap version 10.3.1 was used to analyse the source regions of the dust samples investigated for mineralogical composition. A map was created with 4day back trajectories for days with a dust storm event as depicted on satellite images. In addition, the African surface lithology was included in the map and soils rich in the minerals calcite, kaolinite and chlorite were marked.

Satellite quasi-true colour RGB images (MODIS dataset) were retrieved from the NASA Worldview website (https:// worldview.earthdata.nasa.gov).

Four-day back trajectories at altitudes of 10 (following Stuut et al., 2005), 100, 3000, 4500 (following Skonieczny et al., 2013) and $5500 \mathrm{~m}$ were calculated ending at the dust collector site Iwik $\left(19^{\circ} 52^{\prime} \mathrm{N}, 16^{\circ} 17^{\prime} \mathrm{W}\right)$ and at the proximal marine trap site $\mathrm{CBi}\left(20^{\circ} 46^{\prime}, 18^{\circ} 44^{\prime} \mathrm{W}\right)$ using the Hybrid Single Particle Langrangian Integrated Trajectory (HYSPLIT) model (Stein et al., 2015) and the reanalysis dataset (2.5 spatial resolution) on the NOAA website (http://ready.arl. noaa.gov).

An ArcGIS layer file of the African surface lithology (new_af_lithology_w_glbcvr_waterbdy_90m_dd84_final.lyr) was downloaded from the US Geological survey (USGS) website (http://rmgsc.cr.usgs.gov).

An ArcGIS shape file of the African soils (DSMW.shp) was downloaded from the website of the food and agriculture organization of the United Nations (FAO) (http://www. fao.org). The mean percentages of calcite $(8.9 \%)$, chlorite $(4.1 \%)$ and kaolinite $(29 \%)$ in the clay fraction of Saharan soils in general and for each soil type is given by Journet et al. (2014). Soils with larger percentages of calcite, chlorite or kaolinite in the clay fraction than the average percentages were marked in the ArcGIS map.

\section{Results}

\subsection{Meteorology}

In Fig. 4 the meteorological data of sites Carmen (CB), CBi, Iwik, Arkeiss and Nouâdhibou during 2013 to 2014 are presented (see Fig. 4a for location of the sites). The rainfall frequency is given in Fig. $4 \mathrm{~b}$ for each site. The number of rainfall events were calculated regarding the TRMM stations for precipitation rates $>1 \mathrm{~mm} \mathrm{~d}^{-1}$ because smaller precipitation amounts which were detected by the satellite may not actually reach the ground. Regarding the surface stations Carmen and Arkeiss, a threshold of $>0.2 \mathrm{~mm} \mathrm{~d}^{-1}$ was used in order to exclude events which may be related to anomalously high moisture instead of rainfall.

According to the TRMM satellite product the annual precipitation frequency was larger on the shoreline (station Arkeiss and Iwik) than offshore (station CBi and Carmen) (Fig. 4b). This may be explained by a decrease in atmospheric water vapour content due to precipitation when the winds move westward. Moreover, the TRMM satellite product indicated larger rainfall frequencies during the summer season compared to the winter season regarding the stations Carmen, CBi, Iwik and Arkeiss. Larger summer rainfall frequencies can be explained by the summer northward shift of the ITCZ to $\sim 21^{\circ} \mathrm{N}$ resulting in more frequent moist convection and rainfall in the study area.

The annual rainfall frequency at site Arkeiss and the summer rainfall frequencies at sites Arkeiss and Carmen compare quite well between the sensors and the TRMM observations. However, the spatial and seasonal trends observed by the TRMM data were not supported by the sensor on buoy Carmen and by the surface station in Arkeiss. The larger annual and winter rainfall frequency recorded with the sensor on buoy Carmen may be related to water emission from the ocean surface during time periods with strong surface winds. Further, disagreements between the surface stations and the TRMM stations may be caused by the local signal recorded by the respective rain sensor. A larger number of rain sensors would most likely improve the comparability to the TRMM data.

The wind direction and speed for the surface stations Carmen, Nouâdhibou and Iwik are displayed in Fig. 4c. The annual average surface wind velocity was at a maximum offshore at buoy site Carmen (CB) with $\sim 8 \mathrm{~m} \mathrm{~s}^{-1}$. The buoy recorded a larger average wind velocity during winter than during summer, which is consistent with this season being dominated by the trades. On the shoreline, the average wind velocity was slightly larger during summer than during winter. The predominant annual wind direction was NE at sites Carmen and Iwik, while predominant NW winds were recorded for site Nouâdhibou. The wind direction changed from predominantly NE during winter to a predominantly NNE direction during summer at site Carmen. A similar but less pronounced seasonal trend can be observed for the con- 

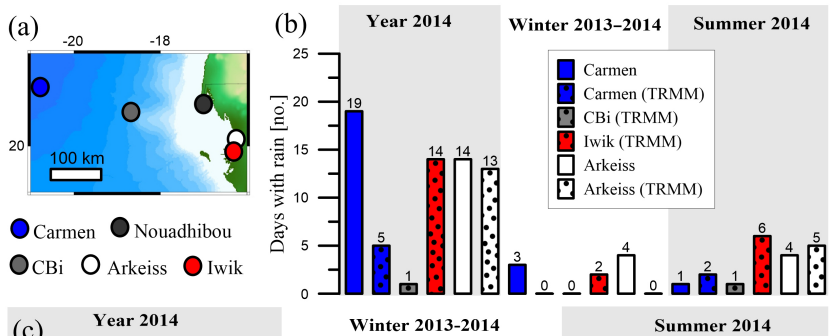

(c) Year 2014

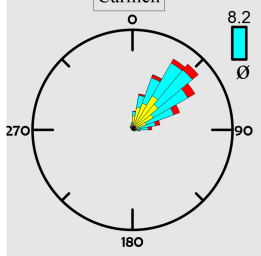

Nouadhibou

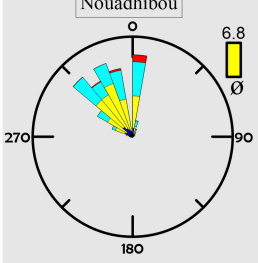

Iwik

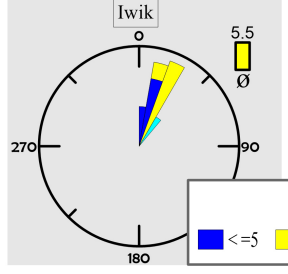

$-8 \quad \square>8-11 \quad \square>11-14$
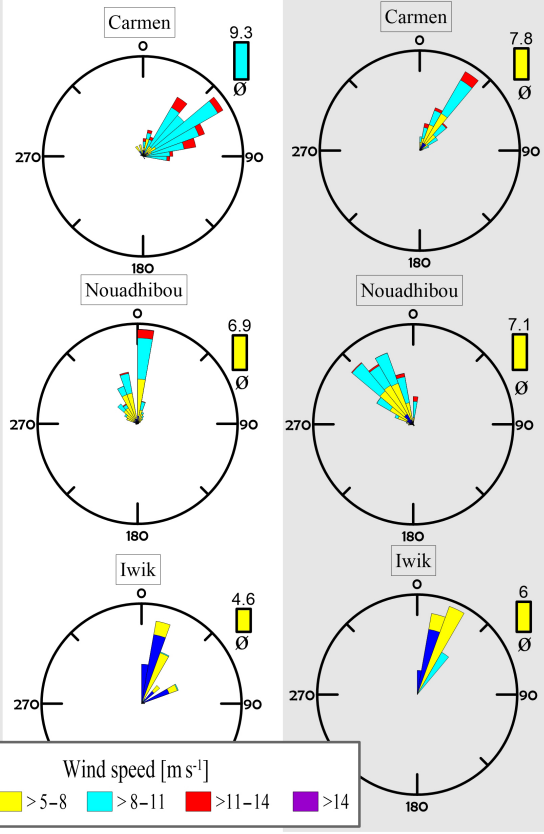

Figure 4. Meteorological data map (a) showing sites Carmen (CB), CBi, Iwik, Nouâdhibou and Arkeiss under investigation; (b) precipitation at sites Carmen (CB), CBi, Iwik and Arkeiss; (c) wind direction and speed at sites Carmen (CB), Nouâdhibou and Iwik.

tinental site Iwik. In Nouâdhibou, the predominant winter wind direction is NNW, switching to a predominantly NW wind direction during summer. Obviously, with winds originating from the open ocean, not a lot of dust is anticipated. Therefore, we interpret these wind directions as being very local and caused by the shape of the peninsula of Cap Blanc.

\subsection{Microscope findings of the dust samples from Iwik}

In Fig. 5 the results of the microscopy investigation of the Iwik 2013 time series are presented. In general, the majority of the particles consisted of angular and moderately spherical quartz grains with a diameter of $\sim 50 \mu \mathrm{m}$ (Fig. 5a, b). A small percentage of large platy minerals with a diameter of $\sim 200 \mu \mathrm{m}$ was found in all samples (Fig. 5b). Large quartz grains with a diameter of $\sim 150$ to $200 \mu \mathrm{m}$ were detected in $45 \%$ of the samples. An anomalously high percentage of subangular and moderately spherical quartz grains with an average diameter of $\sim 200 \mu \mathrm{m}$ was observed in one summer sample (Fig. 5c). Aggregated grains occurred in all sam-

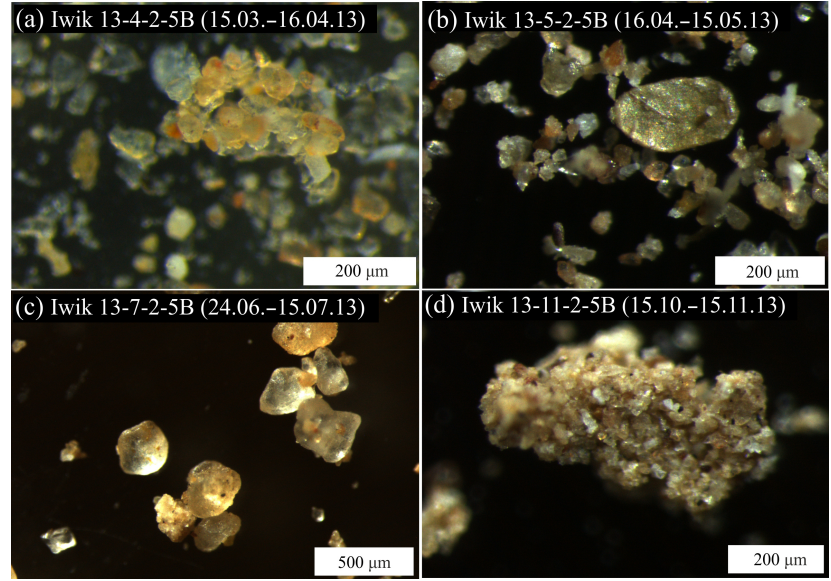

Figure 5. Microscopic photographs of selected dust samples from the Iwik 2013 time series. (a) Spring dust sample with a $\sim 250 \times 150 \mu \mathrm{m}$ aggregate; (b) spring dust sample with a $\sim 200 \times$ $100 \mu \mathrm{m}$ mica chip; (c) summer dust sample with $\sim 200 \times 200 \mu \mathrm{m}$ quartz grains; (d) autumn dust sample with a $\sim 600 \times 250 \mu \mathrm{m} \mathrm{ag}-$ gregate.

ples. However, the percentage and size of the aggregates as well as the size of the aggregated grains differed from sample to sample. Usually, the size of the aggregated grains was $\sim 50 \mu \mathrm{m}$ (Fig. 5a). Two samples were characterized by aggregates composed of particles with a smaller size of $\sim 20 \mu \mathrm{m}$ (Fig. 5d).

\subsection{Dust fluxes and size on land and in the ocean}

In Table 5 the average dust fluxes are given for the sampling sites Iwik, $\mathrm{CBi}$ and $\mathrm{CB}$. The dust concentrations at site Iwik were determined based on the measured wind speed of the meteorological sensor attached to the sampling mast. For four samples no wind data were available due to a failure of the instrument. For these samples a wind velocity was assumed based on the seasonal averages calculated from the available wind data of the meteorology sensor in Iwik (Fig. 4c). The annual average horizontal dust fluxes at site Iwik were of the same order of magnitude during 2013 and 2014. The annual average dust fluxes decreased from the onland site Iwik towards the proximal site $\mathrm{CBi}$ and the distal site CB. At site Iwik the average dust concentration was at a maximum during spring and winter 2013 and 2014, with 393 and $341 \mu \mathrm{g} \mathrm{m}^{-3}$, respectively, and at a minimum in autumn 2013 and 2014, with 48 and $68 \mu \mathrm{g} \mathrm{m}^{-3}$, respectively. The dust fluxes generally decreased with collection height in the mast between 90 and $290 \mathrm{~cm}$ (not shown).

The statistical values of the measured grain-size distributions for the stations $\mathrm{CB}, \mathrm{CBi}$ and Iwik are given in Table 5 . In addition, the measured grain-size distributions for the time series of the stations $\mathrm{CB}, \mathrm{CBi}$ and Iwik are displayed in Fig. 6. In Fig. 6a the average grain-size distribution for the samples of each of the three stations for the year 2013 are 
Table 5. Seasonal and annual average dust fluxes and average modal grain size, mean / mode ratio and standard deviation of the grain-size distributions from Iwik 13-14, CBi 11-12 upper and CB 24 upper time series.

\begin{tabular}{|c|c|c|c|c|}
\hline Series & Year & Winter & Summer & Annual \\
\hline \multicolumn{5}{|c|}{ Average dust fluxes $\left(\mathrm{mg} \mathrm{m}^{-2} \mathrm{~d}^{-1}\right)$ (dust concentration $\left(\mu \mathrm{g} \mathrm{m}^{-3}\right)$ ) } \\
\hline Iwik 13 & 2013 & $10000(30)$ & $113000(268)$ & $95000(214)$ \\
\hline CBi 11 upper & 2013 & 106 & 168 & 99 \\
\hline CB 24 upper & 2013 & 53 & 44 & 45 \\
\hline Iwik 14 & 2014 & $208000(603)$ & $55000(127)$ & $102000(275)$ \\
\hline CBi $11+12$ upper & 2014 & 98 & 20 & 47 \\
\hline \multicolumn{5}{|c|}{ Average modal grain size $(\mu \mathrm{m})$} \\
\hline Iwik 13 & 2013 & 44 & 49 & 48 \\
\hline CBi 11 upper & 2013 & 27 & 39 & 29 \\
\hline CB 24 upper & 2013 & 16 & 17 & 16 \\
\hline Iwik 14 & 2014 & 45 & 49 & 48 \\
\hline CBi $11+12$ upper & 2014 & 34 & 44 & 33 \\
\hline \multicolumn{5}{|l|}{$\mathrm{PM}_{10}($ vol. \%) } \\
\hline Iwik 13 & 2013 & 13 & 18 & 17 \\
\hline CBi 11 upper & 2013 & 31 & 38 & 34 \\
\hline CB 24 upper & 2013 & 34 & 31 & 34 \\
\hline Iwik 14 & 2014 & 13 & 27 & 19 \\
\hline CBi $11+12$ upper & 2014 & 30 & 37 & 31 \\
\hline \multicolumn{5}{|c|}{ Average mean / mode ratio $(\mu \mathrm{m})$} \\
\hline Iwik 13 & 2013 & 0.7 & 0.6 & 0.6 \\
\hline CBi 11 upper & 2013 & 0.5 & 0.3 & 0.5 \\
\hline CB 24 upper & 2013 & 0.7 & 0.8 & 0.7 \\
\hline Iwik 14 & 2014 & 0.6 & 0.4 & 0.6 \\
\hline CBi $11+12$ upper & 2014 & 0.5 & 0.3 & 0.5 \\
\hline \multicolumn{5}{|c|}{ Average standard deviation $(\mu \mathrm{m})$} \\
\hline Iwik 13 & 2013 & 2.8 & 3.1 & 3.0 \\
\hline CBi 11 upper & 2013 & 3.0 & 3.3 & 3.1 \\
\hline CB 24 upper & 2013 & 2.7 & 2.6 & 2.6 \\
\hline Iwik 14 & 2014 & 2.8 & 3.5 & 3.1 \\
\hline CBi $11+12$ upper & 2014 & 3.1 & 3.3 & 3.0 \\
\hline
\end{tabular}

given. The maximum measured particle size decreased from $\sim 223 \mu \mathrm{m}$ on land at site Iwik to $\sim 169 \mu \mathrm{m}$ at the proximal site $\mathrm{CBi}$ and $\sim 140 \mu \mathrm{m}$ at the distal site CB (Fig. 6a). In addition, the average modal grain size decreased from $\sim 48 \mu \mathrm{m}$ at site Iwik to $16 \mu \mathrm{m}$ at site CB (Table 5). Bimodal grainsize distributions were encountered for $23 \%$ of the CBi $11-$ 12 samples, $13 \%$ of the Iwik 13-14 samples and none of the CB 24 samples. The three bimodal distributions of the Iwik 13-14 time series were characterized by an additional smaller coarse-mode population peaking at $\sim 16 \mu \mathrm{m}$ besides the more pronounced and variable larger coarse-mode population peaking at $\sim 42$ to $55 \mu \mathrm{m}$. The three Iwik dust samples characterized by a smaller coarse-mode population were collected during spring, summer (Fig. 6c) and autumn. The eight bimodal grain-size distributions of the CBi 11-12 time series were characterized by a variable, larger coarse-mode population at $\sim 25$ to $35 \mu \mathrm{m}$ and a variable, smaller coarsemode population at $\sim 6$ to $16 \mu \mathrm{m}$. The bimodal distributions were recorded for three winter, three summer (Fig. 6b, c), one spring and one autumn sample. The annual average $\mathrm{PM}_{10}$ percentage was about 2 times larger at the offshore sampling sites $\mathrm{CB}$ and $\mathrm{CBi}$ compared to the onshore sampling site Iwik. On average, about one-third of the dust mass sampled at sites CB and CBi was composed of particles smaller than $10 \mu \mathrm{m}$. The average geometric standard deviation of the CB samples was smaller, with $2.6 \mu \mathrm{m}$ compared to the Iwik and CBi time series with $3.1 \mu \mathrm{m}$ (Table 5). The lowest average mean / mode ratio was recorded for the CBi time series with $\sim 0.5$ (Table 5 ).

In Fig. $6 \mathrm{~b}-\mathrm{c}$ the measured grain-size distributions for winter and summer samples are displayed. The averaged modal grain size for the summer samples was coarser grained com- 


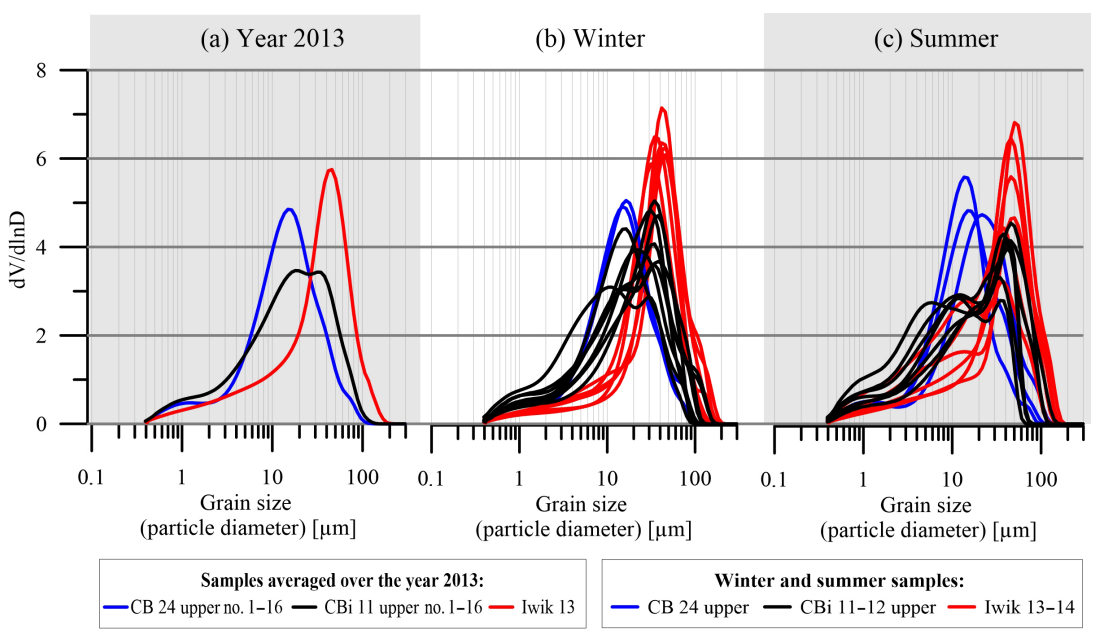

Figure 6. Grain-size distributions of the stations Iwik, CBi and CB (a) averaged for the samples of the year 2013; (b) winter samples; (c) summer samples.

pared to the winter samples of the respective grain-size time series (Table 5). The seasonality in modal grain size was largest for the CBi 11 upper-trap series of the year 2013 with a difference of $\sim 12 \mu \mathrm{m}$ (Table 5). On average, the $\mathrm{PM}_{10}$ percentage was larger for dust sampled during summer compared to winter at sites Iwik and CBi. An opposite, however less pronounced, seasonal trend could be observed for site $\mathrm{CB}$ with generally larger $\mathrm{PM}_{10}$ percentages during winter compared to summer. The average standard deviation was larger and the average mean / mode ratio was smaller in the summer samples compared to the winter samples regarding sites Iwik and CBi (Table 5). This seasonal trend was not observed in the CB 24 upper samples (Table 5).

In Fig. $7 \mathrm{a}-\mathrm{c}$ the results of the correlation between the characteristics of the dust sampled on land and the local meteorological data are presented. In Fig. 7a the particle sizes were correlated to the surface wind speed data $(N=13$ samples). A correlation above a coefficient of determination $\left(R^{2}\right)$ of 0.3 was considered significant at the $95 \%$ confidence level for two-tailed probabilities. The modal particle size of the Iwik samples showed a positive linear correlation with the daily wind speed events with $R^{2}=0.5$, which is significant at the $99.31 \%$ confidence level. The correlation was only evident when using a threshold for wind events of 3.5 to $5.5 \mathrm{~m} \mathrm{~s}^{-1}$ and was best for a threshold of $5 \mathrm{~m} \mathrm{~s}^{-1}$. A better positive linear correlation was obtained when excluding the spring sample resulting in $R^{2}=0.7$, which is significant at the $99.96 \%$ confidence level.

In Fig. 7b the dust fluxes were correlated to the surface wind speed data ( $N=10$ samples). A correlation above $R^{2}=0.4$ was considered significant at the $95 \%$ confidence level for two-tailed probabilities. The horizontal dust flux of the Iwik samples correlated positively to the daily wind speed events during the sampling interval with $R^{2}=0.7$, which is significant at the $99.75 \%$ confidence level. The correlation (a)
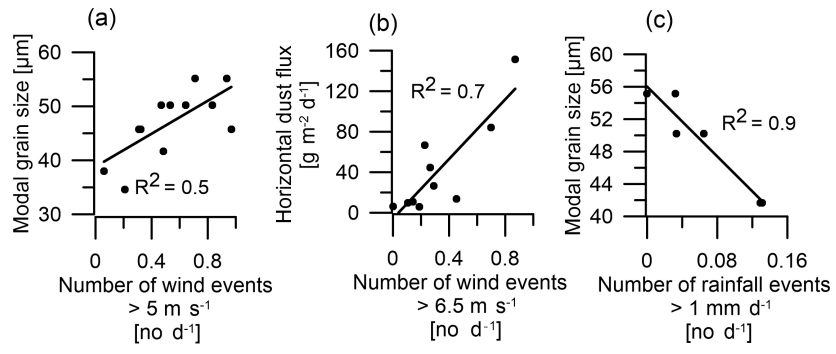

Figure 7. Correlation between the observed local surface wind speed at site Iwik and the measured (a) modal grain size and (b) flux. (c) Correlation between the observed local precipitation at site Iwik (TRMM data) and the modal grain size of the summer samples.

was only evident when using a threshold for wind events of 6.5 to $7 \mathrm{~m} \mathrm{~s}^{-1}$ and was best for a threshold of $6.5 \mathrm{~m} \mathrm{~s}^{-1}$. Moreover, a significant linear correlation with $R^{2}=0.6$ was observed at the $99.15 \%$ confidence level between the dust fluxes and the mean wind strengths during the sampling intervals (not shown).

In Fig. 7c the particle size of the Iwik summer samples was correlated to the local TRMM precipitation data $(N=$ 6 samples). In this case a correlation above $R^{2}=0.7$ was considered significant at the $95 \%$ confidence level for twotailed probabilities. A good linear negative correlation with $R^{2}=0.9$ was observed, which is significant at the $99.78 \%$ confidence level.

\subsection{Mineral assemblage of dust sampled on land and in the ocean}

In Table 6 the mineralogical composition averaged over all eight samples, over the four Iwik samples and over the four CBi samples is given. All dust samples contained the min- 
erals quartz and mica. Further minerals that occurred with significant quantities but which were not present in all dust samples were feldspar, amphibole, zeolite, chlorite and palygorskite. Calcite, dolomite, gibbsite, kaolinite, smectite, sepiolite, fluellite, anhydrite, rutile and serpentine occurred only in some samples, resulting in a low average abundance $\leq 1 \%$. However, we argue that these minerals can be used as dust source indicators because of (1) the characteristic distribution of gibbsite, kaolinite, smectite and sepiolite in North Africa according to different weathering regimes (Biscaye, 1964) and (2) the characteristic occurrence of fluellite, anhydrite, rutile and serpentine according to outcropping rock type (Deer et al., 1992). Further minerals that occur in low abundances $(\leq 3 \%)$ were summarized as "other minerals" and will not be discussed in the paper. While the continental samples were dominated by quartz and feldspar, the marine samples were dominated by mica, followed by quartz and feldspar.

In Fig. 8a-c the results of the mineralogical investigation of the eight dust samples chosen are presented. Figure $8 \mathrm{a}$ again depicts the average composition of the samples per sampling site $(N=4)$. The minerals zeolite, anhydrite, garnet, sepiolite, fluellite, kaolinite and smectite were only found in the marine samples. Only the continental sample of 15 August-15 September 2014 contained traces of zeolite. While gibbsite, serpentine, calcite and dolomite were detected in the continental dust samples, these minerals were absent in all marine samples. The absence of calcite and gibbsite may have been caused by the pretreatment of the marine sediment trap samples with $\mathrm{HCl}$. Although the concentration of the acid used is fairly low (10\%) and the exposure time of the samples was exactly $1 \mathrm{~min}$, we cannot exclude the possibility that carbonate minerals were dissolved. Therefore, the absence of these minerals in the marine traps will not be discussed further.

In the following, the seasonality in the average mineralogical composition will be outlined for each site as given in Fig. $8 \mathrm{~b}$ and c. At site Iwik, the winter dust samples were characterized by the occurrence of chlorite, serpentine and rutile, while the summer samples were characterized by the minerals gibbsite and dolomite. At site $\mathrm{CBi}$, the winter dust samples were characterized by the occurrence of the minerals sepiolite, fluellite, kaolinite, smectite, garnet and anhydrite, while the summer samples were characterized by the mineral rutile. Only for the marine trap samples could an annual average chlorite / kaolinite ratio $(\mathrm{C} / \mathrm{K}=4)$ be derived owing to the occurrence of kaolinite.

\subsection{Identification of dust source regions}

In Figs. 9-12 the results of the 4-day back-trajectory analysis are presented for each sample which has been analysed for mineralogical composition. Four heights (10, 100, 3000 and $4500 \mathrm{~m}$ ) were chosen to cover both low- (trades) and high-level (SAL) dust transport. A back trajectory was 


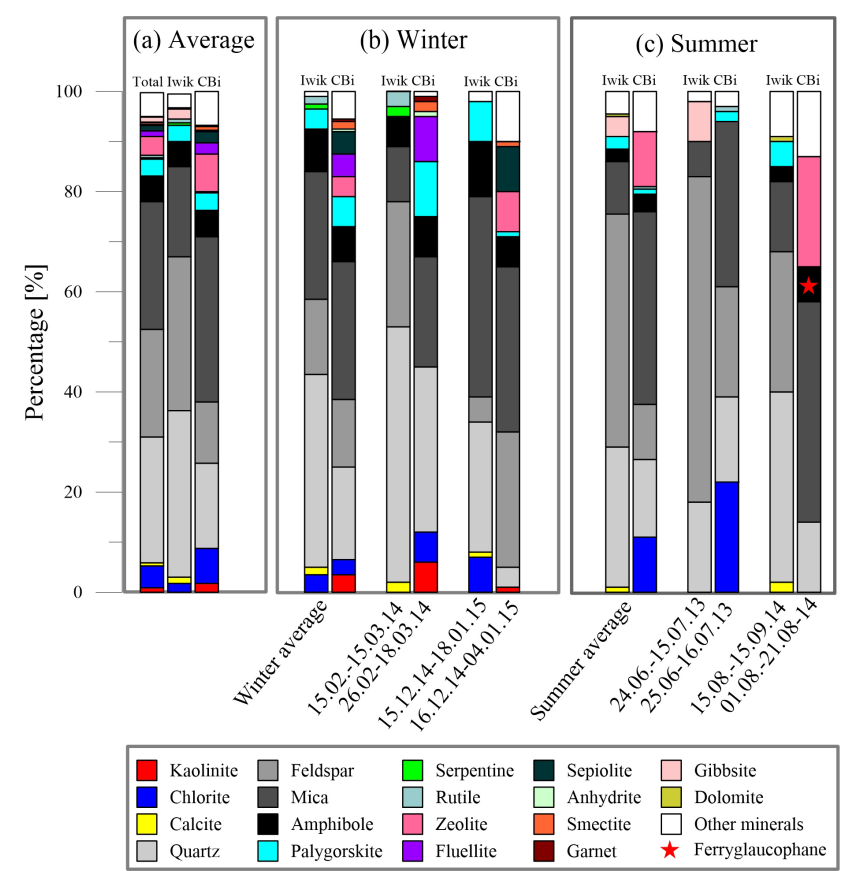

Figure 8. Mineralogical composition (a) averaged over all samples and for sites Iwik and $\mathrm{CBi}$, (b) averaged for the winter samples at sites Iwik and $\mathrm{CBi}$ and for each individual winter sample, and (c) averaged for the summer samples at sites Iwik and $\mathrm{CBi}$ and for each individual summer sample. The category "other minerals" comprises the minerals todorokite, sodalite, koninckite, guyanaite, nitratine, urea, bernalite, akermanite, mixed-layer clay and talc.

drawn for the day when a dust storm event occurred as depicted on satellite images. Only the low-level back trajectories were plotted for site Iwik because of the correlation of the measured dust characteristics with the low-level wind speed. Moreover, the MWAC samplers were designed to only sample dry deposition, whereas the marine sampling sites collect material settling through the water column, i.e. dust resulting from both dry and wet deposition. The back trajectories at $5500 \mathrm{~m}$ can be found in Appendix A.

Figure 9 illustrates a typical late-winter situation. During the sampling interval of each site, at least 2 days with dust storms occurred (Fig. 9c, d). Therefore, two back trajectories were drawn for each height for site CBi and Iwik, respectively. The high-level back trajectories ending at site CBi pass either through the major PSA 2 or point offshore. Both the low-level back trajectories ending at the continental trap site Iwik and at the oceanic trap site $\mathrm{CBi}$ point to a dust source within the major PSA 2 (Scheuvens et al., 2013). Some calcite was present in the continental dust sample, but no chlorite or kaolinite was detected. Therefore, the dust source was most likely located in the nearby southwestern Reguibat Shield where sediments are rich in calcite and quartz and depleted in chlorite and kaolinite (Fig. 9a). Dust deposited in the marine traps during the time interval was characterized by the occurrence of chlorite and kaoli- nite. Thus, the source area of the samples was most likely the chlorite- and kaolinite-rich sediments located near the Boukra phosphate mine in Western Sahara (Fig. 9b).

Figure 10 represents a typical early-winter situation. During the sampling interval of site Iwik, at least three dust storms occurred and at site $\mathrm{CBi}$ at least two dust storms occurred (Fig. 10f-h). Each dust storm lasted for several days for which we could model as many as 15 back trajectories for site Iwik and 8 for site $\mathrm{CBi}$ for each height. The large number of back trajectories complicated the determination of the likely dust source areas. All back trajectories pass through the major PSA 2 and some point to the PSA 1 and 3 (Scheuvens et al., 2013). One high-level back trajectory ending at site CBi passes through PSA 2 and two through Mauritania and Senegal. However, most of the high-level back trajectories ending at site CBi point offshore. Dust sampled in the marine traps during this sampling interval did not contain any chlorite, while the dust trapped at Iwik did. Chlorite may have been supplied to Iwik from a source area nearby the Senegal-Mauritania Basin (Fig. 10a) or as far as the eastern Taoudeni Basin (Fig. 10b) because of the anomalously high chlorite content of the soils in these areas. The continental sample is further characterized by the occurrence of calcite and the absence of kaolinite, which fits the soils of the source areas chosen (Fig. 10a, b). The marine sample was characterized by the occurrence of zeolite and absence of chlorite. Therefore, zeolite may have been derived from the extrusive volcanic rocks of the northern Taoudeni Basin (Fig. 10c). A further source area might be the southern shoreline of Western Sahara, in which chlorite depleted sediments are situated (Fig. 10d). The presence of the mineral kaolinite in this marine winter sample may be explained by a kaolinite-rich source area lying in the southern Senegal-Mauritania Basin (Fig 10e).

In Fig. 11 a typical early-summer situation is presented. Only one dust storm event was observed during the sampling interval at both sites, which lasted for 1 day (Fig. 11c), resulting in only one back trajectory per site and per height. The low-level back trajectory ending at site CBi runs offshore and the high-level back trajectory passes through the major PSAs 2, 3 and 5. The low-level back trajectory ending at site Iwik passes through the major PSA 2 (Scheuvens et al., 2013). Dust sampled on land at site Iwik was characterized by the absence of chlorite, kaolinite and calcite, which fits the soils of northern Tidra Island (Fig. 11a) making it a really local phenomenon. In contrast, dust sampled offshore at site $\mathrm{CBi}$ was characterized by chlorite and by the absence of kaolinite, which fits the chlorite-rich soils in the Mauritanides of Mauritania (Fig. 11b).

In Fig. 12 a typical late-summer situation is illustrated. At least five separate dust events could be identified (Fig. 12f-j), of which three occurred during the sampling interval of site Iwik and two during the sampling interval of site CBi. One of these dust storms occurring during the sampling interval of site CBi lasted for 2 days (7-8 August 2014), while all 


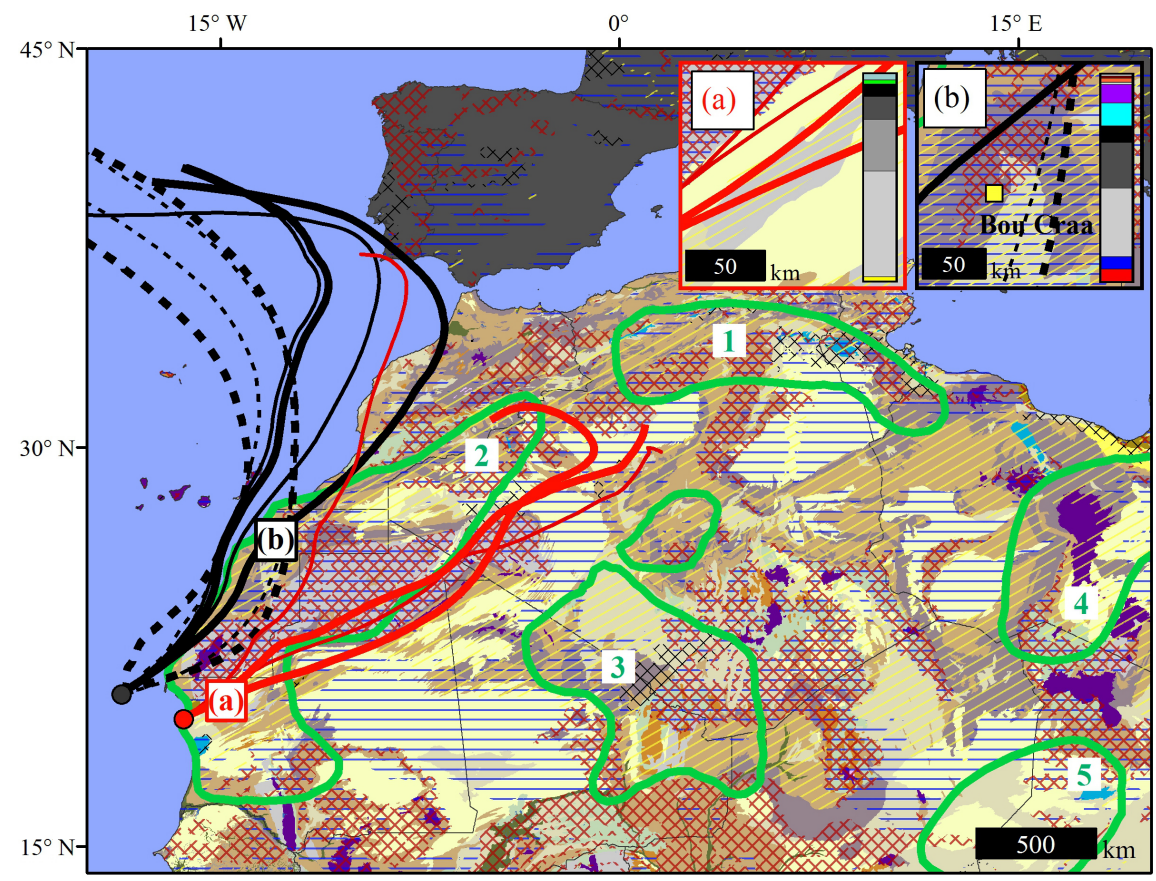

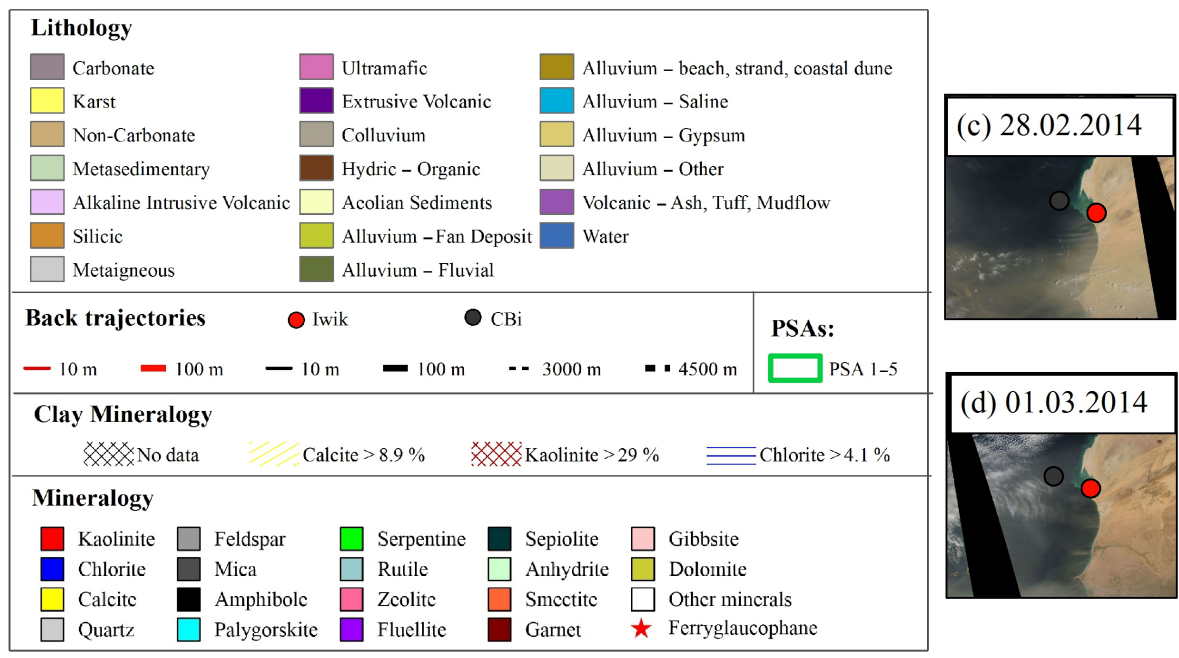

Figure 9. Low-level $(10 \mathrm{~m})$ 4-day back trajectories of dust events ending during the sampling interval 15 February-15 March 2014 at site Iwik and during the sampling interval 26 February-18 March 2014 at site CBi. The potential dust source areas and the mineralogy of the samples are given in the panels (a-b). The dust storm events occurring during the sampling interval are indicated in panels (c-d).

other dust storms lasted for only 1 day. As a result, three back trajectories could be drawn for each site and each height. The low-level back trajectories ending at site CBi run offshore. The low-level back trajectories ending at site Iwik pass through the major PSA 2. The high-level back trajectories pass through the major PSA 2, 3 and 4 (Scheuvens et al., 2013). Dust deposited in the continental traps was characterized by the presence of calcite and the absence of chlorite and kaolinite. Therefore, the source area of the dust was most likely in Western Sahara, where soils rich in calcite but poor in chlorite and kaolinite are located (Fig. 12a, b). Dust sampled with the oceanic traps during this sampling interval was characterized by the absence of chlorite and kaolinite and by the presence of a high percentage of zeolite (22\%) (Fig. 8c). Therefore, a possible source area may have been extrusive volcanic rocks of the northern Taoudeni Basin (Fig. 12c) and the Fezzan uplift (Fig. 12e). Ferroglaucophane may have been sourced by the Pharusian belt (Fig. 12d).

In Fig. 13a-d the mean wind vectors and speed are presented for the dust storm events chosen. The individual dust source areas that were identified using the back trajectory of the day with the dust storm as shown in Figs. 9-12 are further displayed in Fig. 13a-d. As can be clearly seen in the subfigures, the mean wind velocities were anomalously large 


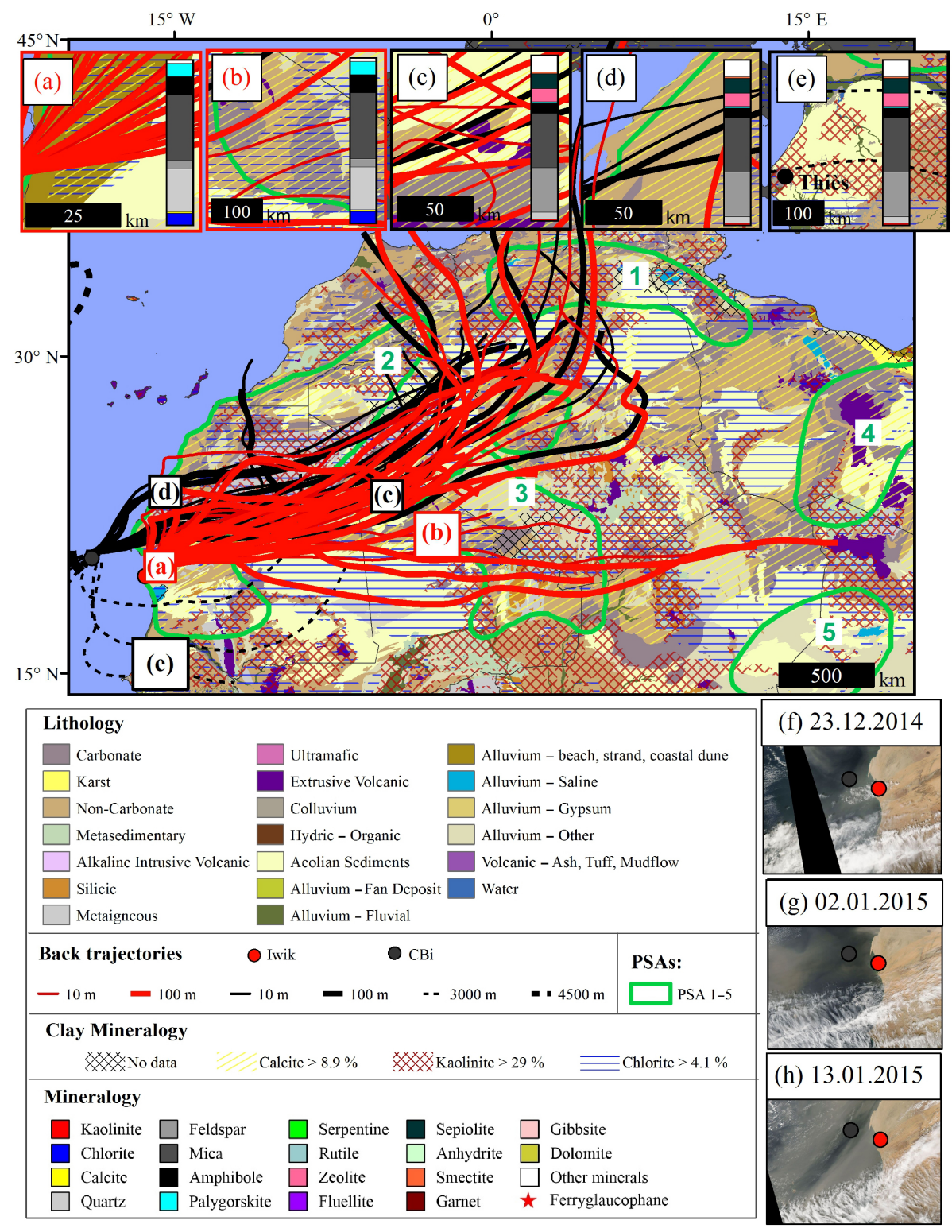

Figure 10. Low-level (10 m) 4-day back trajectories of dust events ending during the sampling interval 15 December 2014-18 January 2015 at site Iwik and during the sampling interval 16 December 2014-4 January 2015 at site CBi. The potential source areas and the mineralogy of the samples are given in panels (a-e). The dust storm events occurring during the sampling interval are indicated in panels $(\mathbf{f}-\mathbf{h})$.

in the dust source areas chosen which enabled dust emission. During winter, six-hourly mean wind velocities were larger than $7 \mathrm{~ms}^{-1}$ in the dust source areas chosen (Fig. 13a-b). During summer 2013, six-hourly mean wind velocities were larger than $6 \mathrm{~m} \mathrm{~s}^{-1}$ in the dust source area chosen (Fig. 13c). During summer 2014 extremely high mean wind velocities were encountered near the study sites and in the dust source area enabling dust emission and transport from a more distant source to site Iwik (Fig. 13d).

\section{Discussion}

\subsection{Comparison of dust collected on land and in the ocean}

\subsubsection{Dust concentrations}

An annual average dust concentration (total suspended particles) of $\sim 214$ and $275 \mu \mathrm{g} \mathrm{m}^{-3}$ was estimated for all dust samples of the year 2013 and 2014, respectively, regarding site Iwik (Table 5). These estimates were larger than what has been measured for background dust concentrations (total suspended particles) in Morocco, which were in the order of 

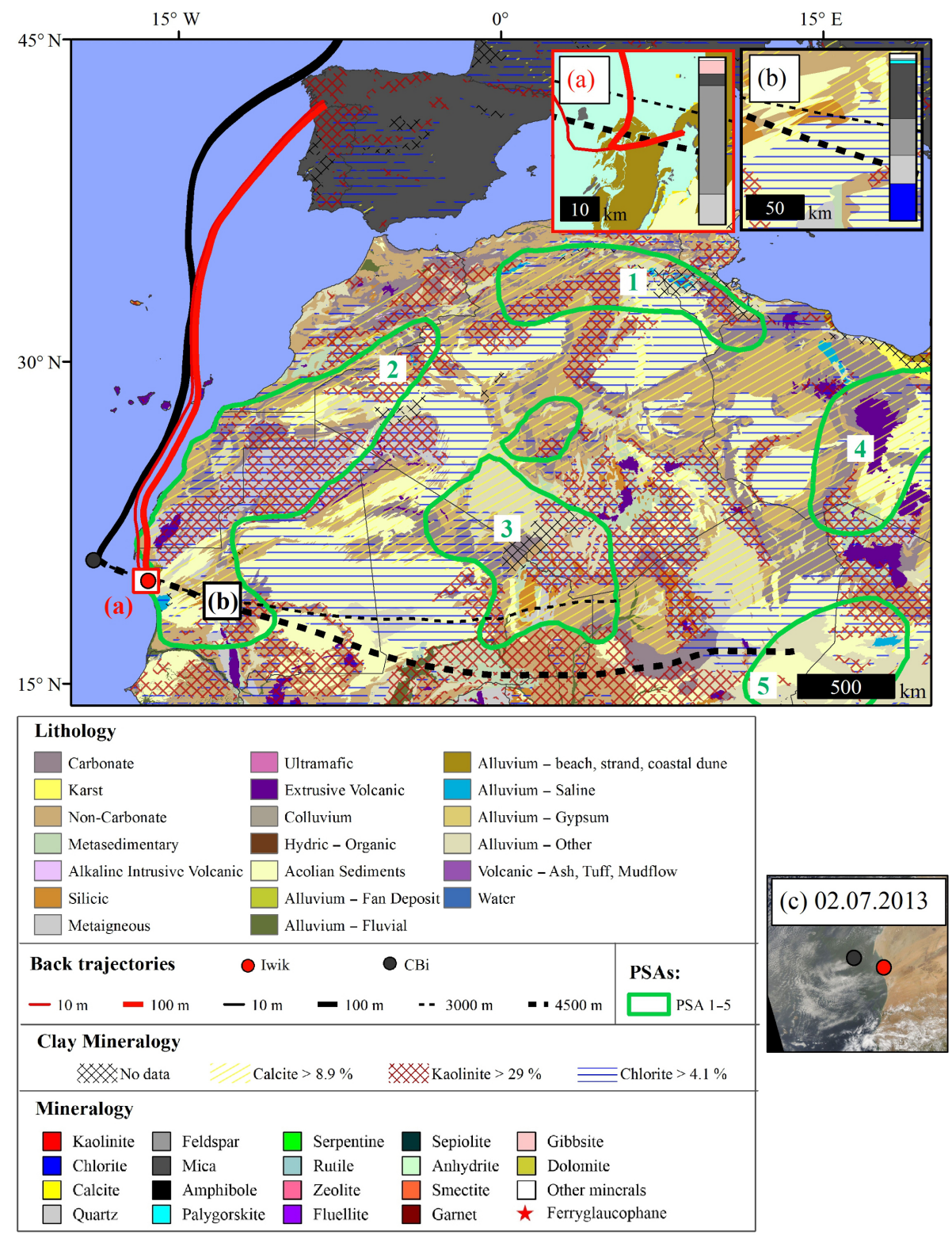

Figure 11. High- $(4500 \mathrm{~m})$ and low-level $(10 \mathrm{~m})$ 4-day back trajectories of a dust event ending during the sampling interval 24 June15 July 2013 at site Iwik and during the sampling interval 25 June-16 July 2013 at site CBi. The potential source areas and the mineralogy of the samples are given in panels $(\mathbf{a}-\mathbf{b})$. The dust storm event is indicated in panel (c).

$100 \mu \mathrm{g} \mathrm{m}^{-3}$ during spring 2006 (Kandler et al., 2009). However, in Morocco dust was collected at a greater height of $4 \mathrm{~m}$ and haze periods and dust storms were excluded from the average value. The horizontal dust fluxes at site Iwik correlated positively with wind speed (Fig. 7b) and decreased with collection height (not shown). This underscores the proximity of this continental site to the dust emission source.

At the distal oceanic site $\mathrm{CB}$, the annual average dust deposition flux was $\sim 45 \mathrm{mg} \mathrm{m}^{-2} \mathrm{~d}^{-1}$ (2013) (Table 5). The dust flux was slightly larger than the average annual dust flux observed at site CB between 1988 and 2012 with $\sim 30 \mathrm{mg} \mathrm{m}^{-2} \mathrm{~d}^{-1}$ (Fischer et al., 2016). The slightly larger dust fluxes may have been caused by the anomalously high frequency in dust storm events as observed on satellite images occurring during the studied time period (not shown). The observed general decrease in the dust flux from site Iwik to sites $\mathrm{CBi}$ and $\mathrm{CB}$ can be explained via the increase in the distance to the source area. Decreased dust deposition fluxes off NW Africa with increasing distance from the African coast were also observed by Bory and Newton (2000) analysing the lithogenic fluxes in marine sediment traps.

The average horizontal fluxes at site Iwik were $\sim 1000$ times larger with $\sim 100000 \mathrm{mg} \mathrm{m}^{-2} \mathrm{~d}^{-1}$ (Table 5) due to 


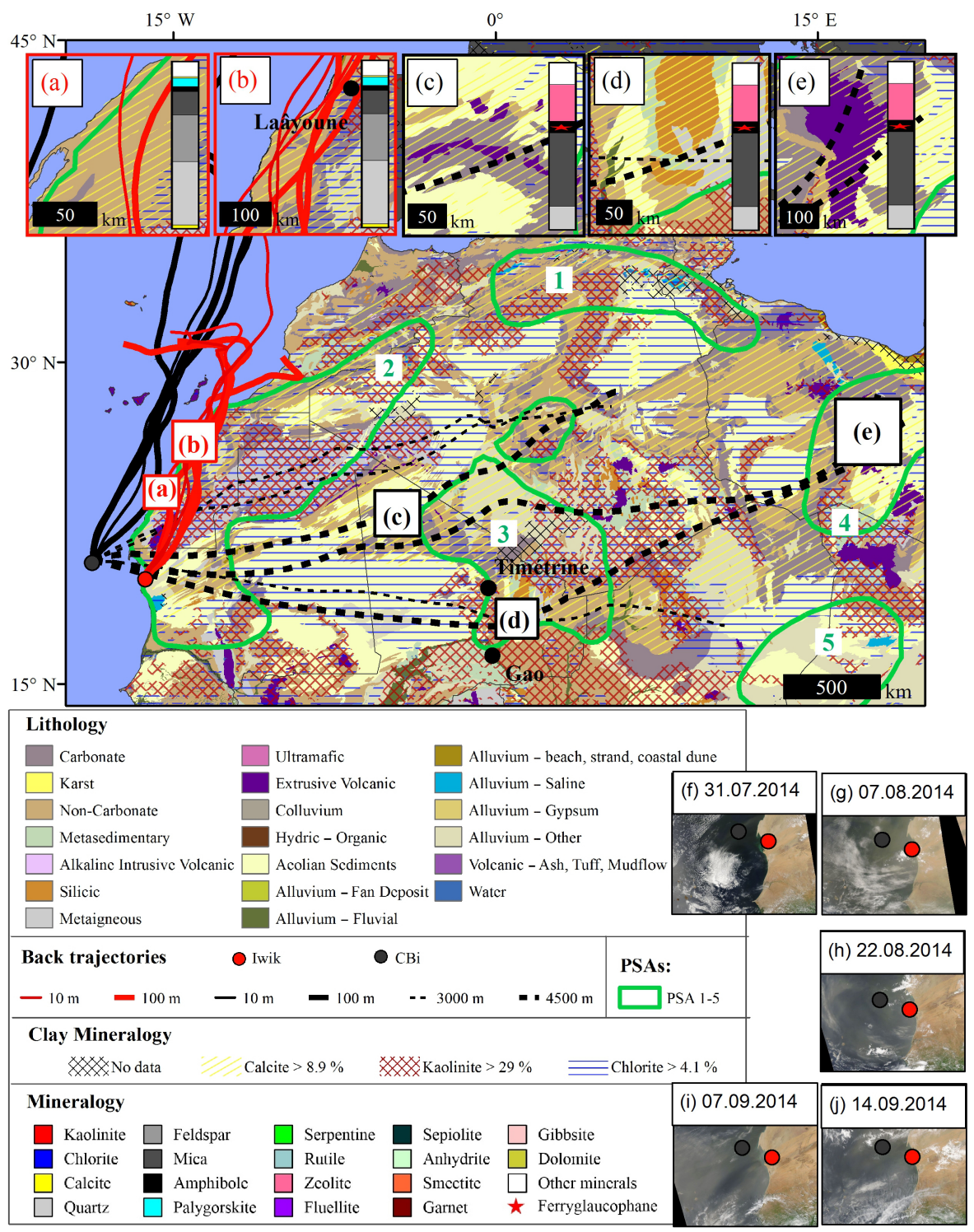

Figure 12. High- $(4500 \mathrm{~m})$ and low-level $(10 \mathrm{~m})$ 4-day back trajectories of dust events ending during the sampling interval 15 August15 September 2014 at site Iwik and during the sampling interval 1-21 August 2014 at site CBi. The potential source areas and the mineralogy of the samples are given in panels $(\mathbf{a}-\mathbf{e})$. The dust storm events are indicated in panels $(\mathbf{f}-\mathbf{j})$.

the different sampling technique. The MWAC samplers do not measure deposition fluxes but instead measure dust concentrations. Only $1 \%$ or less drops out of a moving dust cloud within $5 \mathrm{~min}$; hence, the horizontal dust flux is at least $\sim 100$ times higher than the dust deposition flux (Goossens, 2008). The fact that the dust fluxes decreased with height (not shown) further complicated a comparison between the sites due to the different sampling heights of the dust collectors ( $2.90 \mathrm{~m}$ at Iwik versus sediment traps in the water). Therefore, the fluxes between site Iwik and the offshore sediment trap moorings cannot be compared.

\subsubsection{Dust transport}

The measured grain-size distributions for dust trapped at $2.90 \mathrm{~m}$ on land at site Iwik and for dust settling in the ocean were predominantly unimodal (Fig. 6). Unimodal grain-size distributions are typical for wind-blown sediments (Pye, 1995). Unimodal grain-size distributions were also measured for dust deposited in a vertical dust sampler in M'Bour (Skonieczny et al., 2011) and for dust sampled on ships (Stuut et al., 2005) and in other sediment trap samples off NW Africa (Ratmeyer et al., 1999b; Van der Does et al., 2016; Friese et al., 2016). 


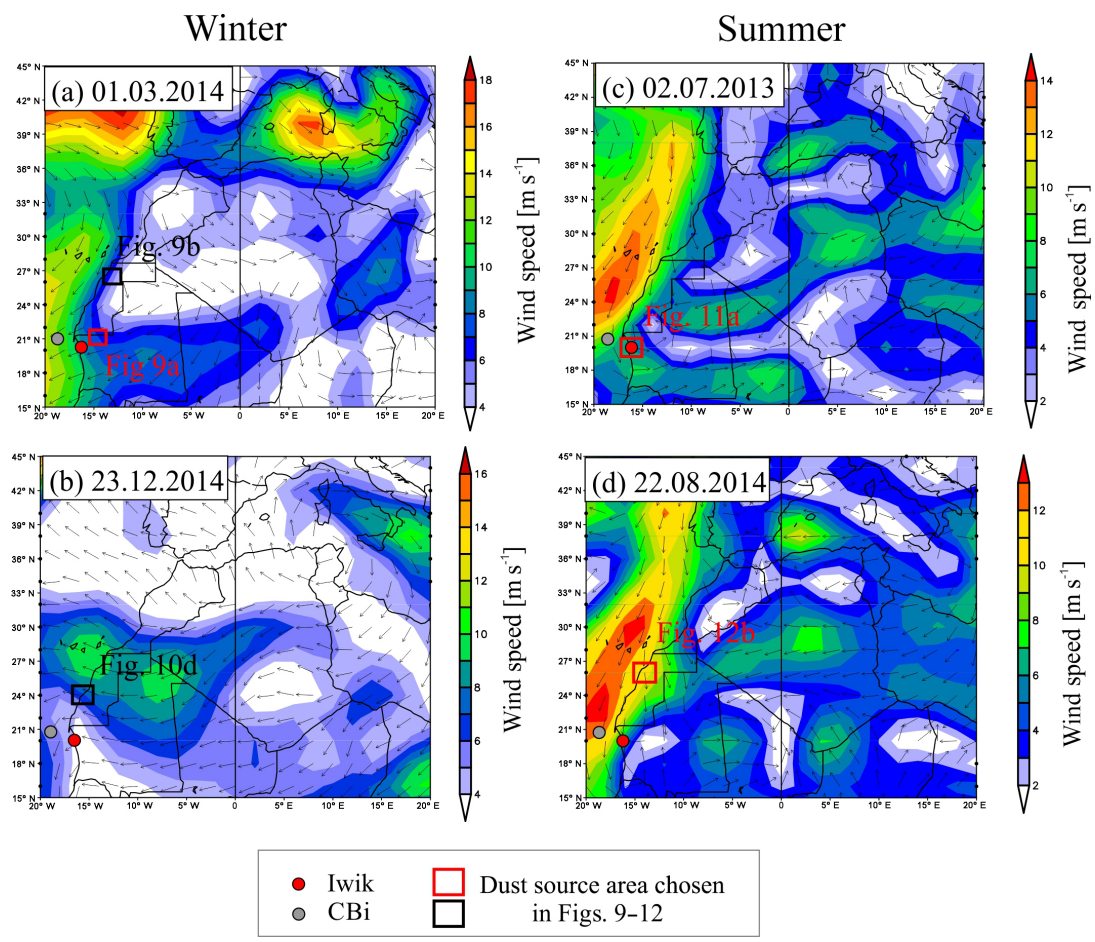

Figure 13. Six-hourly composite mean wind vectors and speed at $1000 \mathrm{mb}$ for selected days including a dust storm event during winter (a-b) and summer (c-d). Furthermore, the dust source area that was identified for the individual dust storm event using the back trajectory of the day with the dust storm is displayed.

The measured annual average modal grain size at site Iwik was $48 \mu \mathrm{m}$ (Table 5). The obtained average annual modal grain size was close to the large coarse-mode population of $44 \mu \mathrm{m}$ observed by Gillies et al. (1996) for dust trapped at a height of $10 \mathrm{~m}$ during spring in Fakarbé (Mali), which is located about $700 \mathrm{~km}$ southeast of Iwik. Gillies et al. (1996) conclude that the large coarse-mode population in the dust samples points to locally derived dust. Based on this observation, we argue that the dust trapped near Iwik was also most likely generally of regional instead of long-distance provenance. The location of the main source area may be, however, not in the direct surrounding of the dust collector since dust sampled with MWAC samplers in the vicinity of barchan dunes of the Bodélé depression at $2.4 \mathrm{~m}$ height is characterized by a larger modal particle size of $\sim 100 \mu \mathrm{m}$ (Chappell et al., 2008). The annual average modal and maximum particle size gradually decreased from the on-land site Iwik to the proximal oceanic site $\mathrm{CBi}$ and the distal oceanic site $\mathrm{CB}$ (Table 5; Fig. 6a). This decrease in particle size between the stations $\mathrm{CB}$ and $\mathrm{CBi}$ was observed before and was attributed to the preferred gravitational settling of coarse particles during dust transport (Friese et al., 2016). Moreover, many studies have confirmed a downwind fining of the terrigenous fraction of surface sediments off NW Africa (Koopmann, 1981; Holz et al., 2004; Fütterer, 1980; Radczewski, 1939; Lange, 1975), and it is intuitively logical.
Bimodal grain-size distributions typically indicate the sampling of different dust sources (Stuut et al., 2009, and references therein). The three samples of the Iwik time series that were characterized by an additional small peak in the grain-size distribution around $\sim 16 \mu \mathrm{m}$ were sampled during sampling intervals of anomalously high wind velocity. The back trajectories of one of these samples pointed towards a proximal and more distal dust source (Fig. 12a, b). Therefore, it may be possible that wind velocities were high enough during the sampling interval to inject dust to a higher altitude and transport it from more distant sources (Fig. 12b) to the sampling site, resulting in the small peak in the grain-size distributions. This interpretation is further supported by the reanalysis wind vector maps showing anomalously high wind velocities between site Iwik and the proposed distant source area, enabling dust emission and transport of dust particles from more distant source to site Iwik (Fig. 13d). On the other hand, microscopic examination prior to particle-size analyses of the Iwik samples revealed that the samples included many aggregates (Fig. 5d). Hence, locally derived aggregates may have been sampled during periods of high wind velocities. These aggregates may have been dispersed in the demineralized water during the measurement of the laser resulting in the observed additional smaller coarse-mode population at $\sim 16 \mu \mathrm{m}$. Further, precipitation was encountered according to the TRMM data during the sampling interval of two of these three samples. Therefore, a further explanation for the bi- 
modal grain-size distributions may be the deposition of dust particles with a mode of $\sim 16 \mu \mathrm{m}$ from higher altitude of the SAL due to precipitation. The rain droplets may have evaporated during their fall, releasing the dust particles at lower altitudes, which can then be sampled with the MWAC sampler. However, we also observed remnants of water in the bottles, and therefore wet deposition into the bottles may have also occurred. During summer, frequent rainfall resulted in a decrease in the modal particle size of deposited Saharan dust at site Iwik (Fig. 7c). In addition, the seasonal average percentage of $\mathrm{PM}_{10}$ particles was larger during summer compared to winter at site Iwik and CBi (Table 5). These observations may also be explained by the deposition of relatively finer dust particles from a higher altitude of the SAL during summer due to precipitation. One winter and one summer sample of the oceanic samples that were characterized by bimodal grain-size distributions have several proposed dust source areas each (Figs. 10, 12). Thus, the sampling of dust that has travelled a long and a short distance may have resulted in a bimodal grain-size distribution.

Both at the onshore sampling site Iwik and at the offshore sampling site $\mathrm{CBi}$, a clear seasonal trend in the particle sizes of deposited dust could be observed with generally coarser modal particle sizes during summer compared to winter (Fig. 6b, c). Generally coarser summer modal particle sizes of deposited dust at site $\mathrm{CBi}$ were observed before for a 3-year time series during 2003 to 2006 and related to moist convective events (Friese et al., 2016). The generally coarser particle sizes during summer at site Iwik compared to winter may be explained by the trade-wind speed as a positive correlation between the modal grain sizes and surface wind velocities was observed (Fig. 7a). This implied that dust was transported with the trade winds from sources of quite a constant distance year-round. During dust storm events, particles with a diameter of 40 to $50 \mu \mathrm{m}$ may be transported $\sim 100 \mathrm{~km}$ (Tsoar and Pye, 1987). The proposed source areas all fall in this range except for the winter sample of 20142015 (Fig. 10). The winter sample was characterized by an anomalously low modal grain size of $38 \mu \mathrm{m}$, and particles of this size may be transported more than $100 \mathrm{~km}$ during dust storm events (Tsoar and Pye, 1987). Moreover, Van der Does et al. (2016) observed how particles up to $100 \mu \mathrm{m}$ were transported $\sim 3500 \mathrm{~km}$ across the Atlantic Ocean. To sum up, the seasonal variability in the modal particle size of deposited dust at site Iwik was mainly driven by the surface wind speed due to the predominant sampling of nearby dust sources yearround.

\subsubsection{Dust mineralogical composition}

In the dust sampled at Iwik the minerals quartz, feldspar, mica, amphibole, palygorskite, chlorite, calcite, dolomite, gibbsite, rutile and serpentine were present (Fig. 8a). The observed occurrence of the minerals quartz, feldspar, mica, chlorite and calcite has also been described for the bulk size fraction of soil samples and dust samples collected in Mauritania (Schütz and Sebert, 1987). Palygorskite, mica and chlorite have also been detected by Skonieczny et al. (2013) in the $\mathrm{PM}_{30}$ size fraction of a 3-year time series of dust deposition at M'Bour, Senegal, more than $500 \mathrm{~km}$ south of Iwik, Mauritania. Smectite and kaolinite, which were absent in the Iwik samples, were the dominant minerals of the dust sampled at M'Bour (Skonieczny et al., 2013). Smectite and kaolinite are considered as indicative of wet tropical soils, and their relative abundance in soils increases southwards along the northwest African coast (Lange, 1982; Biscaye, 1964). We argue that the mineralogical differences between the two sites are explained by the $>500 \mathrm{~km}$ distance between Iwik and M'Bour and the fact that the latter station is surrounded by tropical soils. Gibbsite, rutile and serpentine have not been reported in any continental dust study so far and thus seem to be indicative of locally derived dust (Figs. 9a, 11a).

The dust sampled at the proximal marine site CBi contained the minerals quartz, feldspar, mica, amphibole, palygorskite, chlorite, zeolite, kaolinite, smectite, sepiolite, rutile, garnet, anhydrite and fluellite (Fig. 8a). The first seven of these minerals were also found in the clay and/or silt and sand fraction of Saharan dust sampled during ship cruises parallel to the coast about $70 \mathrm{~km}$ off Cap Blanc (Chester et al., 1971) and perpendicular to the coast about 80 to $180 \mathrm{~km}$ off Cap Blanc (Chester and Johnson, 1971b). Analogous to the samples of this study, the $\mathrm{PM}_{20}$ fraction of surface sediments of the piston cores RC05-57, RC05-60 and A18044 also features zeolites and the surface sediments of core RCRC05-57 also traces of pyrophyllite (sepiolite belongs to the pyrophyllite group) (Biscaye, 1964). Further, rutile was also present in the silt and sand fraction of Saharan dust sampled perpendicular to the coast on the research vessel (Chester and Johnson, 1971b). Palygorskite was found in the clay fraction of the surface sediment of sediment core GIK12329 $\left(19^{\circ} 22^{\prime} \mathrm{N}, 19^{\circ} 56^{\prime} \mathrm{W}\right)$ off Cap Blanc and is considered a characteristic mineral of Saharan dust (Lange, 1975). The observed annual average $C / K$ ratio $(C / K=4)$ recorded for the bulk size fraction of the trap samples was larger than the $\mathrm{C} / \mathrm{K}$ ratio $(\mathrm{C} / \mathrm{K}=0.3-1)$ recorded in the clay fraction of surface sediment samples off Cap Blanc by Lange (1982). The disagreement may be due to the generally larger percentage of kaolinite in the clay fraction compared to the silt fraction (Journet et al., 2014).

The dust samples of site Iwik were further characterized by a dominance in quartz and feldspar (Fig. 8a). A dominance in quartz has also been described for continental dust samples and soil samples collected in Mauritania by Schütz and Sebert (1987). More than 20 papers published XRD data of northern African dust, reporting quartz as the main mineral in most dust samples (Scheuvens et al., 2013). The observed increase in micas and decrease in quartz and feldspar observed for the marine samples relative to the Iwik samples (Fig. 8a) can be explained via the preferential gravitational settling of the larger dust minerals quartz and feldspar during 
Table 7. Overview of the source areas chosen and the tracer minerals of the individual samples, together with the given characteristics of the source areas according to literature.

\begin{tabular}{|c|c|c|c|c|}
\hline $\begin{array}{l}\text { Sampling } \\
\text { interval }\end{array}$ & $\begin{array}{l}\text { Characteristic miner- } \\
\text { als of sample }\end{array}$ & Dust source area chosen & $\begin{array}{l}\text { Bulk mineralogical } \\
\text { composition of } \\
\text { PSA chosen }\end{array}$ & $\begin{array}{l}\text { Characteristic source rocks and de- } \\
\text { posits of source area chosen }\end{array}$ \\
\hline \multicolumn{5}{|l|}{ Iwik } \\
\hline 15 Feb-15 Mar 2014 & Rut, Serp, Cc & PSA 2: Reguibat Shield & $\begin{array}{l}\mathrm{C} / \mathrm{K}=0.0-1.0 \\
\text { Pal: } 1-30 \mathrm{wt} \%\end{array}$ & $\begin{array}{l}\text { Metamorphic and granitic rocks }{ }^{1} \\
\text { Serpentinites }^{2}\end{array}$ \\
\hline $\begin{array}{l}15 \text { Dec } 2014- \\
18 \text { Jan } 2015\end{array}$ & $\mathrm{Cc}, \mathrm{Chl}, \mathrm{Pal}(8 \mathrm{wt} \%)$ & $\begin{array}{l}\text { PSA 2: Senegal- } \\
\text { Mauritania Basin }\end{array}$ & $\begin{array}{l}\mathrm{C} / \mathrm{K}=0.0-1.0 \\
\text { Pal: } 1-30 \mathrm{wt} \%\end{array}$ & Chalky horizons $^{3}$ \\
\hline & & $\begin{array}{l}\text { PSA 3: eastern } \\
\text { Taoudeni Basin }\end{array}$ & $\begin{array}{l}\mathrm{C} / \mathrm{K}=0.2-0.9 \\
\text { Pal: } 1-5 \mathrm{wt} \%\end{array}$ & Carbonate sequences ${ }^{4}$ \\
\hline 24 Jun-15 Jul 2013 & Gib & PSA 2: Tidra Island & $\begin{array}{l}\mathrm{C} / \mathrm{K}=0.0-1.0 \\
\text { Pal: } 1-30 \mathrm{wt} \%\end{array}$ & Gibbsite maximum off Cap Blanc ${ }^{5}$ \\
\hline 15 Aug-15 Sep 2014 & Cc, Dol, Pal (5 wt \%) & $\begin{array}{l}\text { PSA 2: Aaiún-Tarfaya } \\
\text { Basin }\end{array}$ & $\begin{array}{l}\mathrm{C} / \mathrm{K}=0.0-1.0 \\
\text { Pal: } 1-30 \mathrm{wt} \%\end{array}$ & $\begin{array}{l}\text { Limestone deposits }^{6} \\
\text { Outcrops near Laâyoune with } \\
\text { dolomites }^{6}\end{array}$ \\
\hline \multicolumn{5}{|l|}{$\mathrm{CBi}$} \\
\hline 26 Feb -18 Mar 2014 & $\begin{array}{l}\text { Chl, Kao }(\mathrm{C} / \mathrm{K}=1), \\
\text { Pal }(11 \mathrm{wt} \%), \quad \text { Flu, } \\
\text { Anh, Sme, Ga }\end{array}$ & $\begin{array}{l}\text { PSA 2: Aaiún-Tarfaya } \\
\text { Basin near Boukra }\end{array}$ & $\begin{array}{l}\mathrm{C} / \mathrm{K}=0.0-1.0 \\
\text { Pal: } 1-30 \mathrm{wt} \%\end{array}$ & Phosphate deposits ${ }^{7}$ \\
\hline \multirow[t]{3}{*}{$\begin{array}{l}16 \text { Dec } 2014- \\
4 \text { Jan } 2015\end{array}$} & $\begin{array}{l}\text { Kao }(C / K=0), \text { Pal } \\
(1 \mathrm{wt} \%), Z \text { Zeo, Se, Sme }\end{array}$ & $\begin{array}{l}\text { Dike swarms and sills of } \\
\text { northern Taoudeni Basin }\end{array}$ & - & Basalts with glass 9 \\
\hline & & $\begin{array}{l}\text { PSA 2: Aaiún-Tarfaya } \\
\text { Basin }\end{array}$ & $\begin{array}{l}\mathrm{C} / \mathrm{K}=0.0-1.0 \\
\text { Pal: } 1-30 \mathrm{wt} \%\end{array}$ & Palygorskite-sepiolite mafic clays ${ }^{10}$ \\
\hline & & $\begin{array}{l}\text { Southern Senegal- } \\
\text { Mauritania Basin }\end{array}$ & - & $\begin{array}{l}\text { Lateritic soil }^{8} \\
\text { Horizontal layers of palygorskite and } \\
\text { sepiolite }^{8}\end{array}$ \\
\hline 25 Jun-16 Jul 2013 & Chl, Pal (2 wt \%), Rut & PSA 2: Mauritanides & $\begin{array}{l}\mathrm{C} / \mathrm{K}=0.0-1.0 \\
\text { Pal: } 1-30 \mathrm{wt} \%\end{array}$ & $\begin{array}{l}\text { Strongly metamorphosed rocks }{ }^{10} \\
\text { Greenschist facies }\end{array}$ \\
\hline \multirow[t]{3}{*}{ 1-21 Aug 2014} & Fe-Amf, Zeo & $\begin{array}{l}\text { Dike swarms and sills of } \\
\text { northern Taoudeni Basin }\end{array}$ & - & Basalts with glass 9 \\
\hline & & PSA 4: Fezzan uplift & $\begin{array}{l}\mathrm{C} / \mathrm{K}=0.0-2.6 \\
\text { Pal: } 0 \text { wt } \%\end{array}$ & Zeolite in basaltic rocks ${ }^{12,13}$ \\
\hline & & PSA 3: Pharusian belt & $\begin{array}{l}\mathrm{C} / \mathrm{K}=0.2-0.9 \\
\text { Pal: } 1-5 \mathrm{wt} \%\end{array}$ & $\begin{array}{l}\text { Blueschists }{ }^{14} \\
\text { Glaucophane bearing eclogites }^{15}\end{array}$ \\
\hline
\end{tabular}

* Amf: amphibole; Pal: palygorskite; Chl: chlorite; Cc: calcite; Dol: dolomite; Gib: gibbsite; Zeo: zeolite; Kao: kaolinite; Sme: smectite; Se: sepiolite; Ru: rutile; Serp: serpentine; Ga: garnet; Anh: anhydrite; Flu: fluellite. ${ }^{1}$ Schofield et al. (2006) and references therein. ${ }^{2}$ Schlüter (2008). ${ }^{3}$ Wissmann (1982). ${ }^{4}$ Bertrand-Sarfati et al. (1991). ${ }^{5}$ Biscaye (1964). ${ }^{6}$ Bosse and Gwosdz (1996). ${ }^{7}$ Moreno et al. (2006). ${ }^{8}$ García-Romero et al. (2007). ${ }^{9}$ Verati et al. (2005). ${ }^{10}$ Villeneuve (2005). ${ }^{11}$ Dallmeyer and Lécorché (1991). ${ }^{12}$ Abdel-Karim et al. (2013). ${ }^{13}$ Cvetković et al. (2010). ${ }^{14}$ Caby (2014). ${ }^{15}$ Caby et al. (2008). ${ }^{16}$ Scheuvens et al. (2013).

transport (Delany et al., 1967; Glaccum and Prospero, 1980; Chester and Johnson, 1971b; Schütz and Sebert, 1987). A strong downwind decrease in quartz content in Saharan dust was also observed by Korte et al. (2017).

\subsection{Mineralogy as a provenancing tool}

In Table 7 an overview of the dust source areas chosen for site Iwik and $\mathrm{CBi}$ is given together with the characteristic minerals of the samples that may be used as a tracer for the source area. In the following subsections the identification of the source areas and mineralogical tracers is described in detail.

\subsubsection{Dust collected on land}

The variability in the mineralogical composition of dust sampled at site Iwik could be related to the synoptic scale change in the surface trade-wind direction. However, meteorological data from nearby sites, e.g. Nouâdhibou, demonstrate that local effects like the topography exert a strong influence on observed wind directions at ground level (Fig. 4). The back trajectories indicate that the dust sources for the dust collected in Iwik during winter were located $\mathrm{NE}$ and $\mathrm{E}$ of the sampling site (Figs. 9a, 10a, b), while those during summer were located W (within the PNBA) and NNE of the sampling site (Figs. 11a, 12a, b). This is in accordance with a change in the dominant local surface wind direction from NE in win- 
ter to NNE in summer (Fig. 4) and is also reflected in the clay-mineralogical composition of the samples.

Generally, there is not much variability in the claymineralogical composition of the Iwik samples. The back trajectories for the winter sample of 2014 indicate that the material was blown from the southwestern Reguibat Shield (PSA 2) (Fig. 9a). The lack of palygorskite in this sample does not fit the proposed bulk palygorskite content (1-30\%) of PSA 2 (Scheuvens et al., 2013) (Table 7). Therefore, we argue that the sampled dust was most likely derived from a localized source of PSA 2. The sample included the characteristic minerals rutile and serpentine (Table 7), which are usually a result of metamorphic processes (Deer et al., 1992). Indeed, the western Reguibat Shield is composed of metamorphic and granitic rocks (Schofield et al., 2006, and references therein), and the rocks are intruded by serpentinites (Schlüter, 2008). The sample was further characterized by the highest quartz percentage among all samples $(\sim 50 \%)$ (Fig. 8b). The sand dunes of the Azefal sand sea which cover part of the southwestern Reguibat Shield might have sourced these quartz grains (Fig. 9a). The sand dunes may have been fed by outcropping carbonate deposits at the northern rim of the Taoudeni Basin via the NE trade winds leading to anomalously high percentages of calcite in the sand dunes (Fig. 9). Thus, the sand dunes may have also sourced the calcite present in the sample (Fig. 8b).

The winter sample of 2014-2015 was suggested to be sourced from sediments of the northern Senegal-Mauritania Basin (PSA 2) (Fig. 10a) and the eastern rim of the Taoudeni Basin (PSA 3) (Fig. 10b). The palygorskite content of the sample $(8 \%)$ fits the proposed bulk palygorskite content of PSA 2 (Scheuvens et al., 2013) (Table 7). This may point to several externally mixed sources of PSA 2 during transport.

The sample was further characterized by calcite and chlorite (Table 7). The sediments in the northern SenegalMauritania Basin (Fig. 10a) comprise Quaternary chalky horizons (Wissmann, 1982) which may have sourced the calcite. More likely, calcite may have been derived from the Mesozoic carbonate sequences cropping out in the eastern rim of the Taoudeni Basin (Bertrand-Sarfati et al., 1991) (Fig. 10b). A source area lying at the Algerian-Mali border was also suggested for a chlorite and calcite bearing dust sample collected on the Canary Islands (Alastuey et al., 2005). The winter dust sample trapped at site Iwik was further characterized by the lowest feldspar percentage $(\sim 5 \%)$, highest mica percentage ( $\sim 40 \%$ ) (Fig. $8 \mathrm{~b}$ ) and lowest modal grain size $(\sim 38 \mu \mathrm{m})$ among all Iwik dust samples analysed for mineralogy. The Stokes terminal settling velocity is smaller for platy particles than for spherical particles of similar diameter (Santamarina and Cho, 2004). Therefore, a longdistance transport of dust from the eastern Taoudeni Basin to Iwik may have resulted in a depletion in spherical quartz particles (Fig. 5a, b, c) and an enrichment in platy mica particles (Fig. 5b).
The summer sample of 2013 was proposed to be sourced from the nearby northern Tidra Island (PSA 2) (Fig. 11a). Again, the absence of the mineral palygorskite is noteworthy which may point to the sampling of a localized dust source.

The sample was further characterized by the mineral gibbsite (Table 7). The northern Tidra Island is famous for the local occurrence of west Africa's northernmost mangroves (Proske et al., 2008), which grow in humid and warm climates. Humid and warm conditions are also beneficial for the formation of gibbsite which forms through tropical weathering (Deer et al., 1992). Therefore, we argue that the soils of Tidra Island supplied the gibbsite found in the sample. A localized small gibbsite maximum was outlined for the surface sediments off Cap Blanc (Biscaye, 1964), which further supports the view that gibbsite is supplied from a local source. The sample was further characterized by anomalously large moderately spherical quartz grains (Fig. 5c) emphasizing a short travel distance of the dust.

The summer sample of 2014 was most likely sourced by sediments of Western Sahara (PSA 2) (Fig. 12a, b). The palygorskite content of the sample $(5 \%)$ matches the proposed bulk palygorskite content of PSA 2 (Scheuvens et al., 2013) (Table 7). Hence, dust may have been supplied from several dust sources of PSA 2 which were mixed during transport.

The sample was further characterized by calcite and dolomite (Table 7). Sediments outcropping in Western Sahara are composed of Tertiary sediments (Wissmann, 1982) with limestone deposits (Bosse and Gwosdz, 1996) that may explain the calcite found in the sample (Fig. 12a). Upper cretaceous outcrops in the Aaiún-Tarfaya Basin near Laâyoune comprise dolomites (Bosse and Gwosdz, 1996) and could have been the source for the dolomite found in the sample (Fig. 12b). A further evidence for dolomite-bearing dust transport from the Aaiún-Tarfaya Basin is a local dolomite maximum outlined for the surface sediments off Western Sahara (Johnson, 1979). A Saharan dust sample trapped in NE Spain also contained dolomite and calcite and was related to a source area lying in Western Sahara (Avila et al., 1997).

\subsubsection{Dust collected at the marine sites}

The seasonal contrast in the dust transport patterns (highlevel Saharan air layer vs. low-level trades) potentially led to strongly deviating dust sources for the material deposited in the marine trap samples. During winter, the back trajectories indicated that the potential dust source areas were located NE of the sampling site (Figs. 9b, 10c, d), while those during summer were located NE, E and SE of the sampling site (Figs. 11b, 12c, d, e). This large variability in wind patterns can clearly be recognized in the clay-mineralogical compositions of the samples throughout the seasons.

Considering the much larger catchment area of the traps, several dust sources may have been sampled with the traps. As a result, the composition of the analysed samples fit the bulk composition of the PSA chosen well. The back trajecto- 
ries indicate that the winter sample of 2014 originated from Western Sahara (PSA 2) (Fig. 9b). The observed C / K ratio $(\mathrm{C} / \mathrm{K}=1)$ and the palygorskite content $(11 \%)$ are in agreement with the bulk compositional $\mathrm{C} / \mathrm{K}$ ratio $(\mathrm{C} / \mathrm{K}=0-1)$ and palygorskite content of PSA 2 (Scheuvens et al., 2013) (Table 7).

The sample was further characterized by the presence of garnet, fluellite and anhydrite (Table 7). The characteristic occurrence of garnet together with the highest quartz content (33\%; Fig. 8b) among all CBi samples confirms a short transport distance of the trapped dust. The mineral fluellite which is a weathering product of phosphate may have been derived from outcropping phosphate deposits near the Boukra phosphate mine (Moreno et al., 2006) (Fig. 9b). Anhydrite could originate from evaporites along the coast.

The back trajectories of the winter sample of 2014 to 2015 lead to the northern Taoudeni Basin (Fig. 10c) and coastal Western Sahara (PSA 2) (Fig. 10d). The observed C / K ratio $(\mathrm{C} / \mathrm{K}=0)$ and palygorskite content $(1 \%)$ fall within the ranges of these minerals in PSA 2 (Scheuvens et al., 2013) (Table 7).

The sample was further characterized by the mineral zeolite, kaolinite, sepiolite and smectite (Table 7). Zeolites are formed from volcanic glass and tuff and form well-developed crystals in basalts (Deer et al., 1992). Therefore, the source area of the zeolites may have been outcropping volcanic rocks in the northern Taoudeni Basin (Fig. 10c). These rocks belong to mafic dikes and sills which are commonly basalts with dotted patches of glass (Verati et al., 2005). An additional indication for a distant dust source may be the lowest quartz content (4\%) among all samples (Fig. 8b). Palygorskite-sepiolite mafic clays were found in soil samples of Western Sahara (Moreno et al., 2006), which may support a Western Saharan source (Fig. 10d).

Sepiolite belongs to the pyrophyllites, which is a mineral that may also be considered indicative of tropical weathering (Moore and Reynolds, 1989). Moreover, kaolinite is usually considered indicative of tropical weathering and the laterites of the southern Sahara and Sahel (Lange, 1975, 1982; Biscaye, 1964). Outcrops of quaternary laterites as well as outcrops of lower Eocene horizontal layers of palygorskite and sepiolite were described near Thiès in Senegal (García-Romero et al., 2007). Therefore, the kaolinite-rich soils and outcrops in the southern Senegal-Mauritania basin near Thiès (Fig. 10e) may have supplied the kaolinite, sepiolite and palygorskite found in the sample.

Another explanation for the presence of kaolinite and smectite in the sample may be the transport of these minerals from southern latitudes via the poleward-flowing undercurrent to the trap site $\mathrm{CBi}$ (Fig. 1). Kaolinite and smectite were found in the clay fraction of the surface sediments off Senegal (Nizou et al., 2011) and may have been brought into the ocean by the Senegal River and redistributed by ocean currents (Biscaye, 1964). The season of high Senegal River sediment supply is between July and October/November (Gac and Kane, 1986). Assuming a mean speed of $\sim 10 \mathrm{~cm} \mathrm{~s}^{-1}$ of the undercurrent (Mittelstaedt, 1991), it may take about 2 months for the particles to travel a distance of $\sim 500 \mathrm{~km}$ to the trap site CBi. This time delay might explain the observed occurrence of these minerals in the trap samples during winter but not during summer.

Based on the back trajectories, the summer sample of 2013 was suggested to be sourced from the Mauritanides (PSA 2) (Fig. 11b). This is confirmed by the palygorskite content of the sample (2\%) (Scheuvens et al., 2013) (Table 7). Outstanding minerals in this sample are chlorite and rutile (Table 7). Outcrops in the Mauritanides west of the Taoudeni Basin feature strongly metamorphosed rocks (Villeneuve, 2005) and greenschist facies (Dallmeyer and Lécorché, 1991), which may have been the source of the rutile and chlorite.

The reconstructed source area of the summer sample of 2014 was the northern Taoudeni Basin (Fig. 12c), the extrusive volcanics of the Pharusian belt (PSA 3) (Fig. 12d) and the Fezzan uplift (PSA 4) (Fig. 12e). The lack of palygorskite in the sample does fit in with PSA 4 ("not detected") (Scheuvens et al., 2013), suggesting that the provenance of the dust sample may be mainly confined to PSA 4 (Table 7). The sample was further characterized by zeolite and ferroglaucophane (Table 7). The dike swarms and sills of the northern Taoudeni Basin (Verati et al., 2005) (Figs. 10c, 12c) and/or the basalts of the Fezzan uplift (Fig. 12e) may have sourced the zeolite. Indeed, zeolite was described as one of the main secondary minerals in the basaltic rocks of the central Al Haruj Al Abyas basalt flows (Abdel-Karim et al., 2013) and in vesicles of the east Al Haruj basalts (Cvetković et al., 2010) of the Fezzan uplift. Traces of zeolite were also detected in the Iwik sample during this sampling interval. It may be that the zeolite dropped out of the high-altitude dust cloud and was subsequently transported via the surface trade winds to the continental trap site. The presence of ferroglaucophane and the absence of feldspar and chorite in the sample indicate highly metamorphous outcrops constituting the dust source. Therefore, the sample may have been additionally sourced by the Pharusian belt (Fig. 12d) because blueschists were observed in Timétrine (Caby, 2014) and glaucophane bearing eclogites in the Gourma fold and thrust belt north of Gao (Caby et al., 2008). The sample was further characterized by the highest mica content $(44 \%)$ among all samples (Fig. 8c), supporting a large dust transport distance.

\section{Summary and conclusions}

The fluxes, grain-size distributions and the mineral assemblages of the continental trap samples and oceanic sediment trap samples were well comparable to the characteristics of Saharan dust reported for the region. The following main findings were made: 
- A clear seasonal variability in the particle size of mineral dust deposited on land could be observed with generally coarser modal grain sizes during summer compared to winter. The modal particle sizes could be related to the trade-wind speed.

- Dust deposited on the continent was predominantly transported from nearby local sources (Mauritania, Western Sahara, Mali), while dust deposited in the marine traps was transported from proximal (Mauritania, Western Sahara, Mali) and distal sources (Senegal and Libya).

- Some rare characteristic minerals (e.g. ferroglaucophane, rutile, serpentine) could be related to local outcrops in NW Africa.

To conclude, the particle size and mineralogy of Saharan dust recorded in continental climate archives should be inter- preted differently with respect to paleo-environmental conditions compared to marine climate archives; the on-land archive seems to reflect a much more local signal as compared to the regional signal that is recorded in the marine sediments. Given the relationship between particle size and wind strength, we suggest that the particle size in the continental archive in NW Africa may indicate the paleo-wind strength of the trade winds. This is an intuitively logical conclusion, but it has not been demonstrated before so clearly. It should be kept in mind, however, that the wind strength in the sampling location might differ from the wind strength in the source region if the source region is further away. Moreover, the sizes of dust particles present in the source region will influence the grain sizes of deposited dust.

Data availability. The data can be accessed at https://doi.pangaea. de/10.1594/PANGAEA.877807 (Friese et al., 2017). 


\section{Appendix A}

\section{A1 Satellite RGB images}

In Figs. A1-A4 satellite RGB true colour images are shown of the identified dust storms that occurred during the sampling interval of the summer samples of site CBi and were analysed for dust provenance. On 31 July 2014 only little dust can be observed which overlies the sampling location $\mathrm{CBi}$ (Fig. A2). This fits the observed minor percentage of the mineral ferroglaucophane $(7 \%)$ in the sample, which was suggested to be sourced on 31 July 2014 from PSA 3. Zeolite, which was more abundant (22\%) in the dust sample, was therefore most likely derived from PSA 4 due to the major dust storm event occurring on 7 August 2014 (Fig. A3).

\section{A2 Four-day back trajectories}

In Figs. A5-A8 the 4-day back trajectories are shown calculated at the heights 3000,4500 and $5500 \mathrm{~m}$ and ending at site $\mathrm{CBi}$. These high-altitude back trajectories were calculated for the identified summer days with dust storm events (shown in Figs. A1-A4). On the one hand, a height of $4500 \mathrm{~m}$ was chosen by Skonieczny et al. (2013) in a dust provenance study to represent the SAL. On the other hand, a height of $5500 \mathrm{~m}$ was chosen by Ratmeyer et al. (1999a) in a dust transport study to represent the SAL. Maximum wind velocities within the SAL are observed at a height of $\sim 3-4 \mathrm{~km}$ in the area of the Cape Verde Islands during summer according to Carlson and Prospero (1972). Therefore, we also plotted the back trajectories at a height of $3000 \mathrm{~m}$. In order to investigate which air layer should be chosen for provenance studies, the back trajectories of the different heights were compared.

The back trajectories deviated slightly from each other regarding their direction and length. The back trajectories at $3000 \mathrm{~m}$ showed the most deviation. Further, the back trajectories at $4500 \mathrm{~m}$ showed the best agreement with the source areas and the minerals in the samples. Therefore, we chose to use the trajectories at $4500 \mathrm{~m}$ for provenance studies according to Skonieczny et al. (2013).

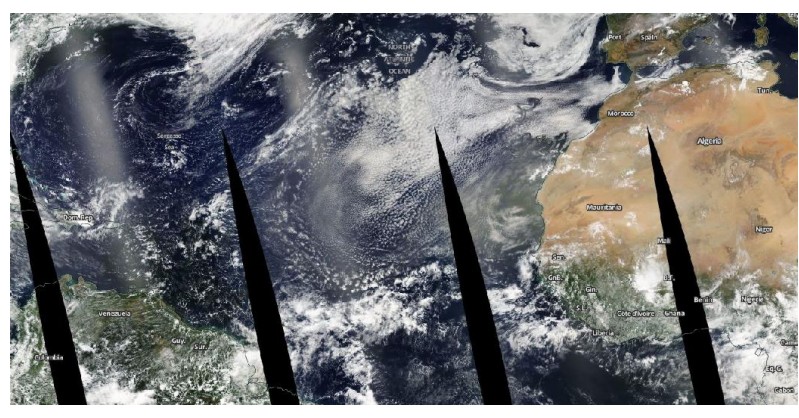

Figure A1. Dust storm on 2 July 2013.

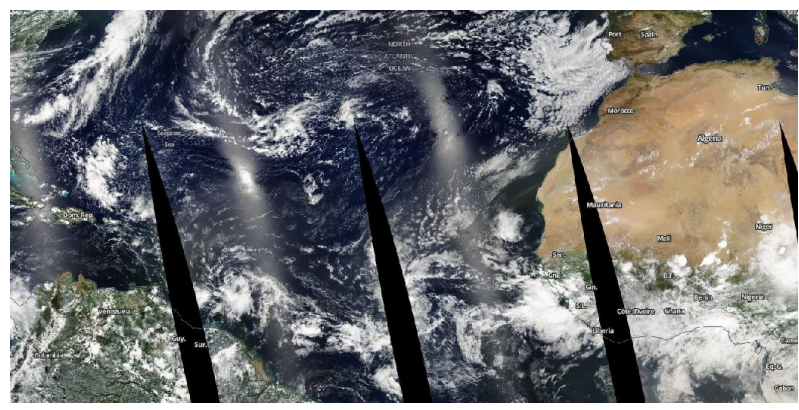

Figure A2. Dust storm on 31 July 2014.

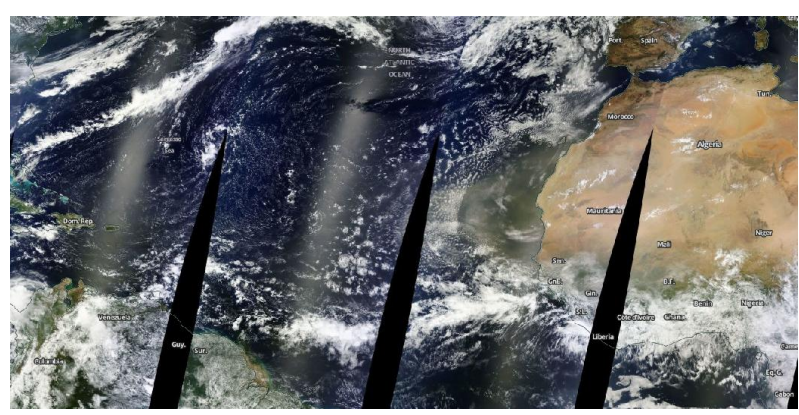

Figure A3. Dust storm on 7 August 2014.

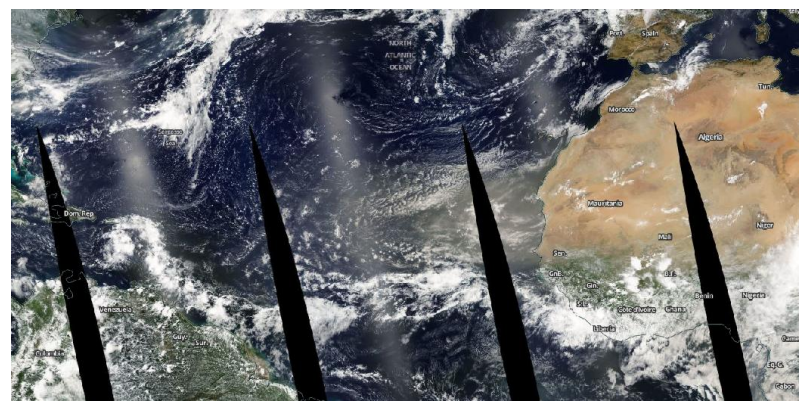

Figure A4. Dust storm on 8 August 2014. 


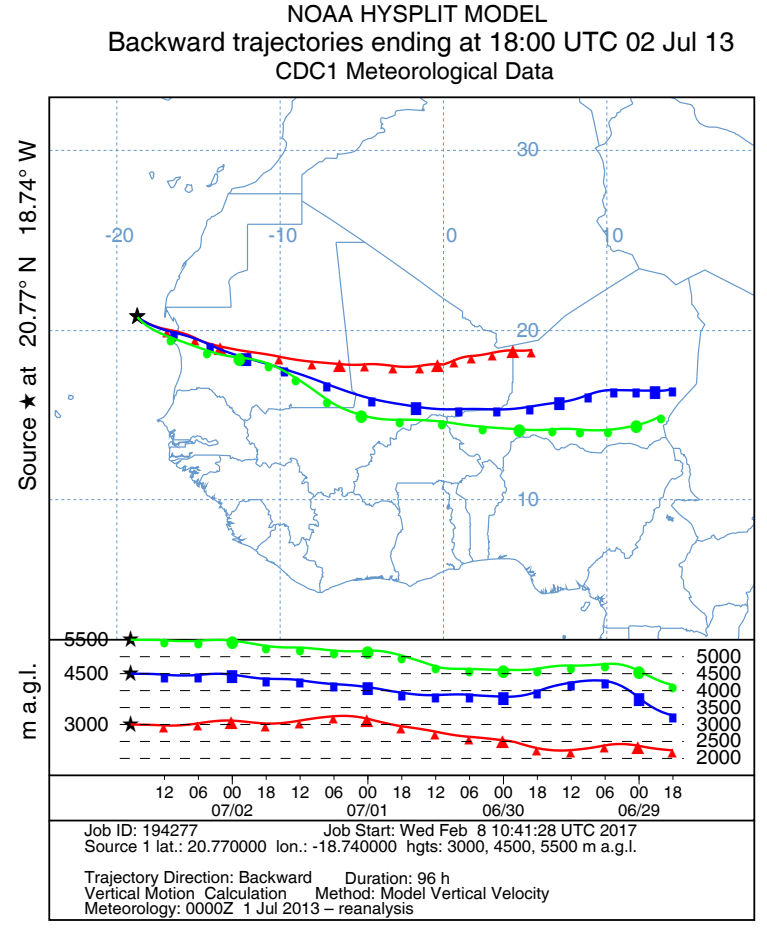

Figure A5. Four-day back trajectories at a height of 3000, 4500 and $5500 \mathrm{~m}$ on 2 July 2013.

NOAA HYSPLIT MODEL Backward trajectories ending at 18:00 UTC 31 J ul 14 CDC1 Meteorological Data

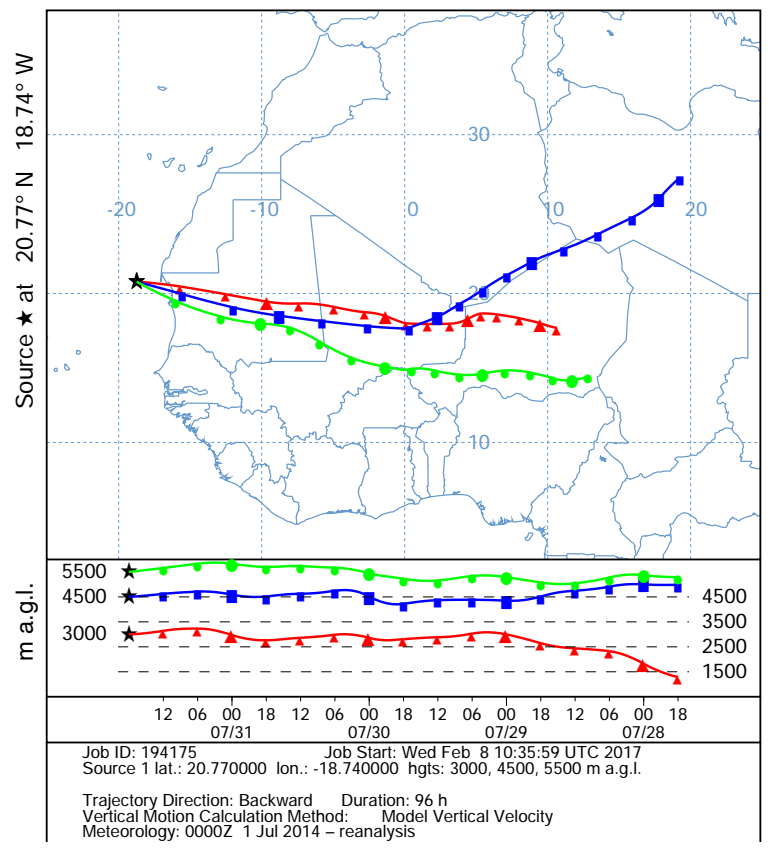

Figure A6. Four-day back trajectories at a height of 3000, 4500 and $5500 \mathrm{~m}$ on 31 July 2014.
NOAA HYSPLIT MODEL

Backward trajectories ending at 18:00 UTC 07 Aug 14 CDC1 Meteorological Data

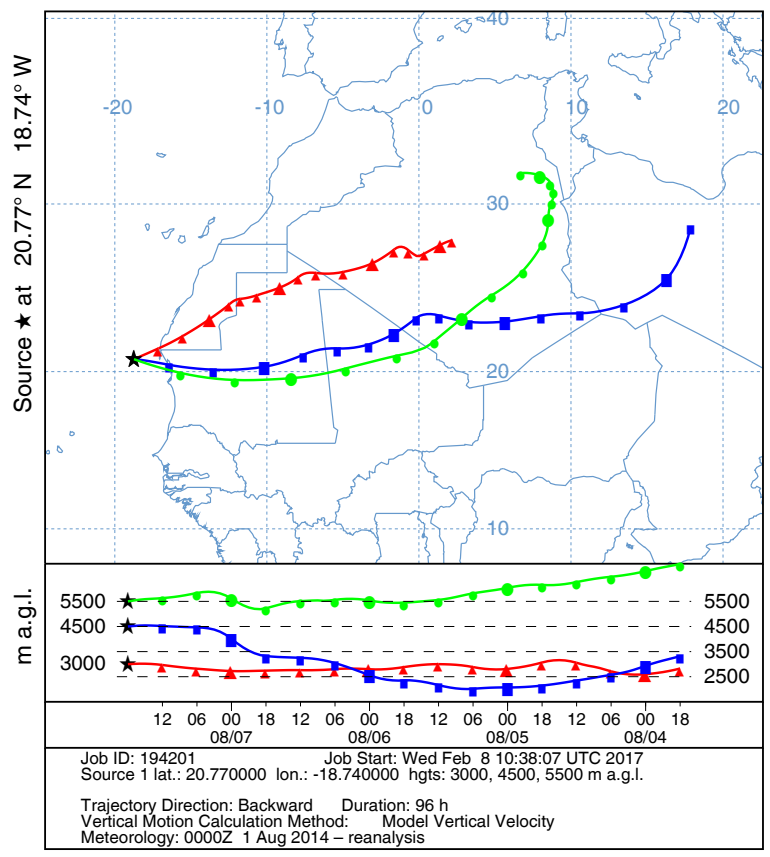

Figure A7. Four-day back trajectories at a height of 3000, 4500 and $5500 \mathrm{~m}$ on 7 August 2014.

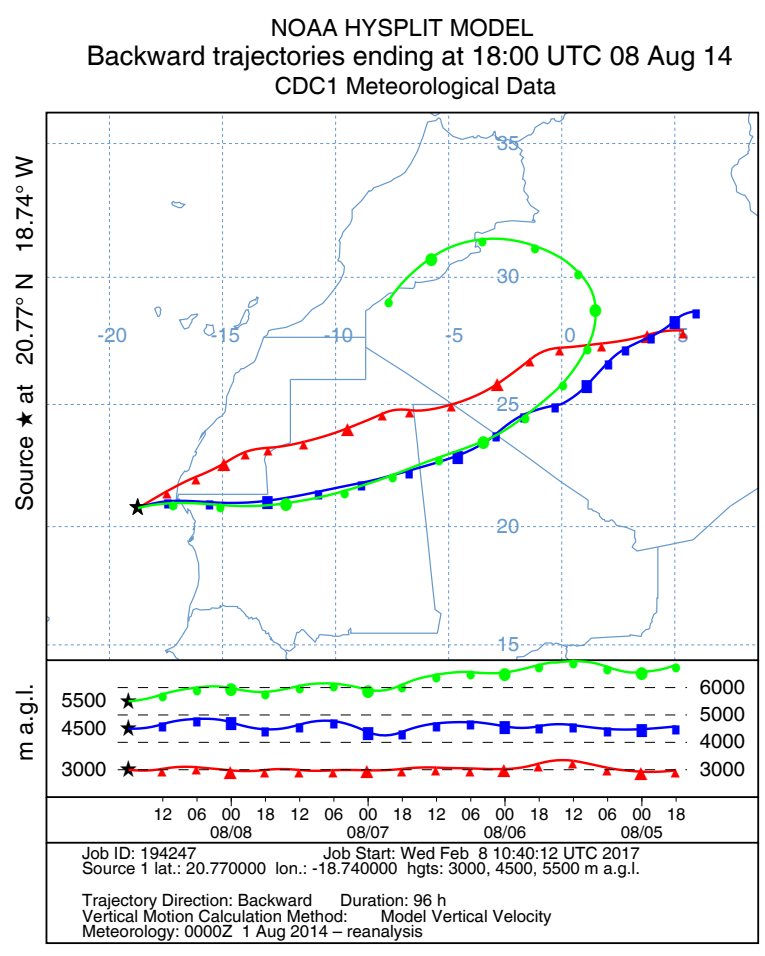

Figure A8. Four-day back trajectories at a height of 3000, 4500 and $5500 \mathrm{~m}$ on 8 August 2014. 
Author contributions. CAF carried out the particle-size analysis of the sediment trap samples. JAvH carried out the flux and particlesize analysis of the Iwik dust samples. GF provided the sediment trap samples and supervised the flux analysis of the sediment trap samples. CAF prepared the samples for XRD analysis. CV carried out the XRD analysis and was involved in the discussion of the results. JBWS managed the projects through which dustcollecting buoy CAF was constructed and deployed and supervised the particle-size analysis and the writing of the paper. CAF prepared the paper with contributions from all co-authors.

Competing interests. The authors declare that they have no conflict of interest.

Special issue statement. This article is part of the special issue "The Saharan Aerosol Long-range Transport and Aerosol-Cloudinteraction Experiment (SALTRACE) (ACP/AMT inter-journal SI)". It is not associated with a conference.

Acknowledgements. We thank the captains, crews and scientific teams of the research cruises with RV Poseidon in 2013 (POS445), RV Poseidon in 2014 (POS464) and RV Poseidon in 2015 (POS481), during which the sediment traps were deployed and received. Further, we thank Marco Klann for preparing and splitting the sediment trap samples. Jan-Berend Stuut acknowledges funding from ERC Grant 311152 DUSTTRAFFIC. Funding is acknowledged from the German Science Foundation (DFG) through the DFG-Research Center/Cluster of Excellence "The Ocean in the Earth System". We further thank Dierk Hebbeln and Ute Merkel for helpful and productive scientific discussions.

The article processing charges for this open-access publication were covered by the University of Bremen.

Edited by: Joshua Schwarz

Reviewed by: two anonymous referees

\section{References}

Abdel-Karim, A.-A. M., Ramadan, E.-N. M., and Embashi, M. R.: Multiphase Alkaline Basalts of Central Al-Haruj Al-Abyad of Libya: Petrological and Geochemical Aspects, J. Geol. Res., 2013, 805451, https://doi.org/10.1155/2013/805451, 2013.

Alastuey, A., Querol, X., Castillo, S., Escudero, M., Avila, A., Cuevas, E., Torres, C., Romero, P.-M., Exposito, F., and García, O.: Characterisation of TSP and $\mathrm{PM}_{2.5}$ at Izana and Sta. Cruz de Tenerife (Canary Islands, Spain) during a Saharan Dust Episode (July 2002), Atmos. Environ., 39, 4715-4728, 2005.

Aston, S. R., Chester, R., Johnson, L. R., and Padgham, R. C.: Eolian dust from the lower atmosphere of the eastern Atlantic and Indian oceans, China Sea and Sea of Japan, Mar. Geol., 14, 1528, 1973.

Avila, A., Queralt-Mitjans, I., and Alarcon, M.: Mineralogical composition of African dust delivered by red rains over northeastern Spain, J. Geophys. Res., 102, 21977-21996, 1997.
Bertrand-Sarfati, J., Moussine-Pouchkine, A., Affaton, P., Trompette, R., and Bellion, Y.: Cover sequences of the West African craton, in: The West African orogens and circumAtlantic correlatives, Springer, Berlin, Heidelberg, 65-82, 1991.

Biscaye, P.: Mineralogy and sedimentation of recent Deep-sea clay in the Atlantic Ocean and adjacent seas and oceans, Geol. Soc. Am. Bull., 76, 803-832, 1965.

Biscaye, P. E.: Mineralogy and sedimentation of the deep-sea sediment fine fraction in the Atlantic Ocean and adjacent seas and oceans, PhD, Geology, Yale University, Michigan, 86 pp., 1964.

Bloemsma, M. R., Zabel, M., Stuut, J. B. W., Tjallingii, R., Collins, J. A., and Weltje, G. J.: Modelling the joint variability of grain size and chemical composition in sediments, Sediment. Geol., 280, 135-148, https://doi.org/10.1016/j.sedgeo.2012.04.009, 2012.

Bory, A. J. M. and Newton, P. P.: Transport of airborne lithogenic material down through the water column in two contrasting regions of the eastern subtropical North Atlantic Ocean, Global Biogeochem. Cy., 14, 297-315, https://doi.org/10.1029/1999gb900098, 2000.

Bosse, H.-R. and Gwosdz, W.: Limestone and dolomite resources of Africa, Geologisches Jahrbuch Reihe D, 500, 278-286 and 478-482, 1996.

Boullier, A.-M.: The pan-African trans-Saharan belt in the Hoggar shield (Algeria, Mali, Niger): A review, in: The west African orogens and circum-Atlantic correlatives, Springer, Berlin Heidelberg, 85-105, 1991.

Caby, R.: Nature and evolution of Neoproterozoic ocean-continent transition: Evidence from the passive margin of the West African craton in NE Mali, J. Afr. Earth Sci., 91, 1-11, https://doi.org/10.1016/j.jafrearsci.2013.11.004, 2014.

Caby, R., Buscail, F., Dembele, D., Diakite, S., Sacko, S., and Bal, M.: Neoproterozoic garnet-glaucophanites and eclogites: new insights for subduction metamorphism of the Gourma fold and thrust belt (eastern Mali), Geological Society, London, Special Publications, 297, 203-216, 2008.

Caquineau, S., Gaudichet, A., Gomes, L., and Legrand, M.: Mineralogy of Saharan dust transported over northwestern tropical Atlantic Ocean in relation to source regions, J. Geophys. Res., 107, 4251, https://doi.org/10.1029/2000JD000247, 2002.

Carlson, T. N. and Prospero, J. M.: The Large-Scale Movement of Saharan Air Outbreaks over the Northern Equatorial Atlantic, J. Appl. Meteorol., 11, 283-297, 1972.

Chappell, A., Warren, A., O'Donoghue, A., Robinson, A., Thomas, A., and Bristow, C.: The implications for dust emission modeling of spatial and vertical variations in horizontal dust flux and particle size in the Bodélé Depression, Northern Chad, J. Geophys. Res.-Atmos., 113, D04214, https://doi.org/10.1029/2007JD009032, 2008.

Chester, R. and Johnson, L. R.: Atmospheric dusts collected off the Atlantic coasts of North Africa and the Iberian Peninsula, Mar. Geol., 11, 251-260, 1971a.

Chester, R. and Johnson, L. R.: Atmospheric dusts collected off the West African Coast, Nature, 229, 105-107, 1971b.

Chester, R., Elderfield, H., and Griffin, J. J.: Dust transported in the North-east and South-east Trade Winds in the Atlantic Ocean, Nature, 233, 474-476, https://doi.org/10.1038/233474a0, 1971. 
Chester, R., Elderfield, H., Griffin, J., Johnson, L., and Padgham, R.: Eolian dust along the eastern margins of the Atlantic Ocean, Mar. Geol., 13, 91-105, 1972.

Chung, F. H.: Quantitative interpretation of X-ray diffraction patterns of mixtures. I. Matrix-flushing method for quantitative multicomponent analysis, J. Appl. Crystallogr., 7, 519-525, 1974.

Cropper, T. E., Hanna, E., and Bigg, G. R.: Spatial and temporal seasonal trends in coastal upwelling off Northwest Africa, 1981-2012, Deep-Sea Res. Pt. I, 86, 94-111, https://doi.org/10.1016/j.dsr.2014.01.007, 2014.

Cvetković, V., Toljić, M., Ammar, N. A., Rundić, L., and Trish, K. B.: Petrogenesis of the eastern part of the Al Haruj basalts (Libya), J. Afr. Earth Sci., 58, 37-50, https://doi.org/10.1016/j.jafrearsci.2010.01.006, 2010.

Dallmeyer, R. D. and Lécorché, J.-P.: The West African orogens and circum-Atlantic correlatives, Springer, Heidelberg Berlin, 1991.

Deer, W. A., Howie, R. A., and Zussman, J.: An introduction to the rock-forming minerals, Longman Scientific \& Technical, Harlow, Essex, UK, 1992.

Delany, A. C., Claire Delany, A., Parkin, D. W., Griffin, J. J., Goldberg, E. D., and Reimann, B. E. F.: Airborne dust collected at Barbados, Geochim. Cosmochim. Ac., 31, 885-909, 1967.

Diaz, H. F., Carlson, T. N., and Prospero, J. M.: A Study of the Structure and Dynamics of the Saharan Air Layer Over the Northern Equatorial Atlantic During BOMEX, Nr. 32, NOAA Technical Memorandum ERL WMPO, Boulder, Colorado, 1976.

Diester-Haass, L. and Chamley, H.: Neogene paleoenvironment off NW Africa based on sediments from DSDP Leg 14, J. Sediment. Res., 48, 879-896, 1978.

Dobson, M.: An account of the Harmattan, a singular African wind, Philos. T. R. Soc. Lond., 71, 46-57, 1781.

Einsele, G., Herm, D., and Schwarz, H. U.: Sea level fluctuation during the past $6000 \mathrm{yr}$ at the coast of Mauritania, Quaternary Res., 4, 282-289, https://doi.org/10.1016/0033-5894(74)900179, 1974.

El Makkrouf, A. A.: Tectonic interpretation of Jabal Eghei area and its regional application to Tibesti orogenic belt, south central Libya (S.P.L.A.J.), J. Afr. Earth Sci., 7, 945-967, https://doi.org/10.1016/0899-5362(88)90009-7, 1988.

Filipsson, H. L., Romero, O. E., Stuut, J.-B. W., and Donner, B.: Relationships between primary productivity and bottom-water oxygenation off northwest Africa during the last deglaciation, J. Quaternary Sci., 26, 448-456, https://doi.org/10.1002/jqs.1473, 2011.

Fischer, G. and Karakas, G.: Sinking rates and ballast composition of particles in the Atlantic Ocean: implications for the organic carbon fluxes to the deep ocean, Biogeosciences, 6, 85102, https://doi.org/10.5194/bg-6-85-2009, 2009.

Fischer, G. and Wefer, G.: Sampling, Preparation and Analysis of Marine Particulate Matter, Geoph. Monog. Series, 63, 391-397, 1991.

Fischer, G., Ba, M., Dehning, K., Hefter, J., Iversen, M., Klann, M., Nowald, N., Ploug, H., Ruhland, G., and Witte, Y.: Report and preliminary results of R/V POSEIDON cruise POS445. Las Palmas-Las Palmas, 19.01.2013-01.02.2013, MARUM, Universität Bremen, 2013.

Fischer, G., Dehning, K., Dia, A., Füssel, J., Hefter, J., Iversen, M., Klann, M., Nowald, N., Olbrich, M., and Ruhland, G.: Report and preliminary results of RV POSEIDON cruise POS464,
Las Palmas (Canary Islands)-Las Palmas (Canary Islands), 03.02.2014-18.02.2014, MARUM, Universität Bremen, 2014.

Fischer, G., Dia, A., Iversen, M., Klann, M., Nowald, N., Markussen, T., Meckel, S., Ruhland, G., Van der Jagt, H., and Waldmann, C.: Report and preliminary results of R/V POSEIDON cruise POS481, Las Palmas (Canary Islands)-Las Palmas (Canary Islands), 15.03.2015-03.03.2015, MARUM, Universität Bremen, 2015.

Fischer, G., Romero, O., Merkel, U., Donner, B., Iversen, M., Nowald, N., Ratmeyer, V., Ruhland, G., Klann, M., and Wefer, G.: Deep ocean mass fluxes in the coastal upwelling off Mauritania from 1988 to 2012: variability on seasonal to decadal timescales, Biogeosciences, 13, 3071-3090, https://doi.org/10.5194/bg-13-3071-2016, 2016.

Formenti, P., Rajot, J. L., Desboeufs, K., Caquineau, S., Chevaillier, S., Nava, S., Gaudichet, A., Journet, E., Triquet, S., Alfaro, S., Chiari, M., Haywood, J., Coe, H., and Highwood, E.: Regional variability of the composition of mineral dust from western Africa: Results from the AMMA SOP0/DABEX and DODO field campaigns, J. Geophys. Res.-Atmos., 113, D00C13, https://doi.org/10.1029/2008JD009903, 2008.

Friese, C. A., van der Does, M., Merkel, U., Iversen, M. H., Fischer, G., and Stuut, J.-B. W.: Environmental factors controlling the seasonal variability in particle size distribution of modern Saharan dust deposited off Cape Blanc, Aeolian Research, 22, 165179, https://doi.org/10.1016/j.aeolia.2016.04.005, 2016.

Friese, C. A., van Hateren, H., Vogt, C., Fischer, G., and Stuut, J.B. W.: Supplementary data to: Seasonal provenance changes of present-day Saharan dust collected on- and offshore Mauritania, PANGAEA, https://doi.org/10.1594/PANGAEA.877807, 2017.

Fütterer, D.: Sedimentation am NW-afrikanischen Kontinentalrand: Quantitative Zusammensetzung und Verteilung der Siltfraktion in den Oberflächensedimenten, Meteor-Forschungsergebnisse, C, 15-60, 1980.

Gac, J. Y. and Kane, A.: Le Fleuve Sénégal: I. Bilan hydrologique et flux continentaux de matières particulaires a l'embouchure, Sci. Géol. Bull., 39, 99-130, 1986.

García-Romero, E., Suárez, M., Santarén, J., and Alvarez, A.: Crystallochemical Characterization of the Palygorskite and Sepiolite from the Allou Kagne Deposit, Senegal, Clay. Clay Miner., 55, 606-617, https://doi.org/10.1346/CCMN.2007.0550608, 2007.

Gillies, J. A., Nickling, W. G., and McTainsh, G. H.: Dust concentrations and particle-size characteristics of an intense dust haze event: inland delta region, Mali, West Africa, Atmos. Environ., 30, 1081-1090, 1996.

Glaccum, R. A. and Prospero, J. M.: Saharan aerosols over the tropical North Atlantic - mineralogy, Mar. Geol., 37, 295-321, 1980.

Goossens, D.: Relationships between horizontal transport flux and vertical deposition flux during dry deposition of atmospheric dust particles, J. Geophys. Res.-Earth, 113, F02S13, https://doi.org/10.1029/2007JF000775, 2008.

Goossens, D. and Offer, Z. Y.: Wind tunnel and field calibration of six aeolian dust samplers, Atmos. Environ., 34, 1043-1057, https://doi.org/10.1016/s1352-2310(99)00376-3, 2000.

Griffin, J. J., Windom, H., and Goldberg, E. D.: The distribution of clay minerals in the World Ocean, Deep-Sea Res., 15, 433-459, https://doi.org/10.1016/0011-7471(68)90051-X, 1968.

Haywood, J. and Boucher, O.: Estimates of the direct and indirect radiative forcing due to tropospheric aerosols: A review, Rev. 
Geophys., 38, 513-543, https://doi.org/10.1029/1999rg000078, 2000

Holz, C., Stuut, J.-B. W., and Henrich, R.: Terrigenous sedimentation processes along the continental margin off NW-Africa: implications from grain-size analyses of surface sediments, Sedimentology, 51, 1145-1154, https://doi.org/10.1111/j.13653091.2004.00665.x, 2004.

Holz, C., Stuut, J.-B. W., Henrich, R., and Meggers, H.: Variability in terrigenous sedimentation processes off northwest Africa and its relation to climate changes: Inferences from grain-size distributions of a Holocene marine sediment record, Sediment. Geol., 202, 499-508, https://doi.org/10.1016/j.sedgeo.2007.03.015, 2007.

Iversen, M. H. and Ploug, H.: Ballast minerals and the sinking carbon flux in the ocean: carbon-specific respiration rates and sinking velocity of marine snow aggregates, Biogeosciences, 7 , 2613-2624, https://doi.org/10.5194/bg-7-2613-2010, 2010.

Iversen, M. H. and Robert, M. L.: Ballasting effects of smectite on aggregate formation and export from a natural plankton community, Mar. Chem., 175, 18-27, https://doi.org/10.1016/j.marchem.2015.04.009, 2015.

Iversen, M. H., Nowald, N., Ploug, H., Jackson, G. A., and Fischer, G.: High resolution profiles of vertical particulate organic matter export off Cape Blanc, Mauritania: Degradation processes and ballasting effects, Deep-Sea Res. Pt. I, 57, 771-784, https://doi.org/10.1016/j.dsr.2010.03.007, 2010.

Jickells, T. D., An, Z. S., Andersen, K. K., Baker, A. R., Bergametti, G., Brooks, N., Cao, J. J., Boyd, P. W., Duce, R. A., Hunter, K. A., Kawahata, H., Kubilay, N., laRoche, J., Liss, P. S., Mahowald, N., Prospero, J. M., Ridgwell, A. J., Tegen, I., and Torres, R.: Global Iron Connections Between Desert Dust, Ocean Biogeochemistry, and Climate, Science, 308, 67-71, 2005.

Johnson, L. R.: Mineralogical dispersal patterns of North Atlantic deep-sea sediments with particular reference to eolian dusts, Mar. Geol., 29, 335-345, https://doi.org/10.1016/00253227(79)90115-4, 1979.

Journet, E., Balkanski, Y., and Harrison, S. P.: A new data set of soil mineralogy for dust-cycle modeling, Atmos. Chem. Phys., 14, 3801-3816, https://doi.org/10.5194/acp-14-3801-2014, 2014.

Kandler, K., Schütz, L., Deutscher, C., Ebert, M., Hofmann, H., Jäckel, S., Jaenicke, R., Knippertz, P., Lieke, K., Massling, A., Petzold, A., Schladitz, A., Weinzierl, B., Wiedensohler, A., Zorn, S., and Weinbruch, S.: Size distribution, mass concentration, chemical and mineralogical composition and derived optical parameters of the boundary layer aerosol at Tinfou, Morocco, during SAMUM 2006, Tellus B, 61, 32-50, https://doi.org/10.1111/j.1600-0889.2008.00385.x, 2009.

Khiri, F., Ezaidi, A., and Kabbachi, K.: Dust deposits in SoussMassa basin, South-West of Morocco: granulometrical, mineralogical and geochemical characterisation, J. Afr. Earth Sci., 39, 459-464, 2004.

Knippertz, P. and Todd, M. C.: Mineral dust aerosols over the Sahara: Meteorological controls on emission and transport and implications for modeling, Rev. Geophys., 50, RG1007, https://doi.org/10.1029/2011RG000362, 2012.

Knippertz, P. and Stuut, J.-B. W.: Mineral dust a key player in the Earth system, Springer, Dordrecht, 2014.
Koch, J. and Renno, N. O.: The role of convective plumes and vortices on the global aerosol budget, Geophys. Res. Lett., 32, L18806, https://doi.org/10.1029/2005GL023420, 2005.

Kogbe, C. A.: Geology of the upper cretaceous and tertiary sediments of the Nigerian sector of the Iullemeden Basin (West-Africa), Geol. Rundsch., 62, 197-211, https://doi.org/10.1007/bf01826827, 1973.

Koopmann, B.: Sedimentation von Saharastaub im subtropischen Nordatlantik während der letzten 25.000 Jahre, Meteor Forschungsergebnisse C, 35, 23-59, 1981.

Korte, L. F., Brummer, G.-J. A., van der Does, M., Guerreiro, C. V., Hennekam, R., van Hateren, J. A., Jong, D., Munday, C. I., Schouten, S., and Stuut, J.-B. W.: Downward particle fluxes of biogenic matter and Saharan dust across the equatorial North Atlantic, Atmos. Chem. Phys., 17, 6023-6040, https://doi.org/10.5194/acp-17-6023-2017, 2017.

Lange, H.: Herkunft und Vertei-lung von Oberflachensedimenten des westafrikanischen Schelfs und Kontinentalhanges, "Meteor" Forschungsergeb., 22, 61-84, 1975.

Lange, H.: Distribution of Chlorite and Kaolinite in Eastern Atlantic Sediments Off North-Africa, Sedimentology, 29, 427-431, https://doi.org/10.1111/j.1365-3091.1982.tb01805.x, 1982.

Lau, K. M. and Kim, K. M.: Cooling of the Atlantic by Saharan dust, Geophys. Res. Lett., 34, L23811, https://doi.org/10.1029/2007GL031538, 2007.

Martin, J. H.: Glacial-interglacial $\mathrm{CO}_{2}$ change: the iron hypothesis, Paleoceanography, 5, 1-13, 1990.

Martin, J. H., Gordon, R. M., and Fitzwater, S. E.: The case for iron, Limnol. Oceanogr., 36, 1793-1802, 1991.

McTainsh, G. H., Nickling, W. G., and Lynch, A. W.: Dust deposition and particle size in Mali, West Africa, Catena, 29, 307-322, 1997.

Mendez, M. J., Funk, R., and Buschiazzo, D. E.: Field wind erosion measurements with Big Spring Number Eight (BSNE) and Modified Wilson and Cook (MWAC) samplers, Geomorphology, 129, 43-48, 10.1016/j.geomorph.2011.01.011, 2011.

Meunier, T., Barton, E. D., Barreiro, B., and Torres, R.: Upwelling filaments off Cap Blanc: Interaction of the NW African upwelling current and the Cape Verde frontal zone eddy field?, J. Geophys. Res.-Oceans, 117, C08031, https://doi.org/10.1029/2012JC007905, 2012.

Meyer, I., Davies, G. R., Vogt, C., Kuhlmann, H., and Stuut, J.-B. W.: Changing rainfall patterns in NW Africa since the Younger Dryas, Aeolian Research, 10, 111-123, https://doi.org/10.1016/j.aeolia.2013.03.003, 2013.

Mittelstaedt, E.: The ocean boundary along the northwest African coast: Circulation and oceanographic properties at the sea surface, Prog. Oceanogr., 26, 307-355, https://doi.org/10.1016/0079-6611(91)90011-A, 1991.

Moore, D. M. and Reynolds, R. C.: X-ray Diffraction and the Identification and Analysis of Clay Minerals, Oxford university press, Oxford, 1989.

Moreno, T., Querol, X., Castillo, S., Alastuey, A., Cuevas, E., Herrmann, L., Mounkaila, M., Elvira, J., and Gibbons, W.: Geochemical variations in aeolian mineral particles from the SaharaSahel Dust Corridor, Chemosphere, 65, 261-270, 2006.

Mulitza, S., Heslop, D., Pittauerova, D., Fischer, H. W., Meyer, I., Stuut, J.-B., Zabel, M., Mollenhauer, G., Collins, J. A., Kuhnert, H., and Schulz, M.: Increase in African dust flux at the onset of 
commercial agriculture in the Sahel region, Nature, 466, 226228, https://doi.org/10.1038/nature09213, 2010.

Müller, P. J. and Schneider, R.: An automated leaching method for the determination of opal in sediments and particulate matter, Deep-Sea Res. Pt I, 40, 425-444, https://doi.org/10.1016/09670637(93)90140-X, 1993.

National Geospatial-Intelligence Agency: North Atlantic, Baltic Sea, North Sea and Mediterranean Sea, 4th Edn., Sailing directions (planning guide), ProStar Publications, 2006.

Nicholson, S. E.: A revised picture of the structure of the "monsoon" and land ITCZ over West Africa, Clim. Dynam., 32, 11551171, https://doi.org/10.1007/s00382-008-0514-3, 2009.

Nizou, J., Hanebuth, T. J. J., and Vogt, C.: Deciphering signals of late Holocene fluvial and aeolian supply from a shelf sediment depocentre off Senegal (north-west Africa), J. Quaternary Sci., 26, 411-421, https://doi.org/10.1002/jqs.1467, 2011.

Piqué, A.: Geology of northwest Africa, Gebrüder Borntraeger, Berlin, 2001.

Ploug, H., Iversen, M. H., and Fischer, G.: Ballast, sinking velocity, and apparent diffusivity within marine snow and zooplankton fecal pellets: Implications for substrate turnover by attached bacteria, Limnol. Oceanogr., 53, 1878-1886, 2008a.

Ploug, H., Iversen, M. H., Koski, M., and Buitenhuis, E. T.: Production, oxygen respiration rates, and sinking velocity of copepod fecal pellets: Direct measurements of ballasting by opal and calcite, Limnol. Oceanogr., 53, 469-476, https://doi.org/10.4319/lo.2008.53.2.0469, 2008b.

Proske, U., Hanebuth, T. J. J., Meggers, H., and Leroy, S. A. G.: Tidal flat sedimentation during the last millennium in the northern area of Tidra Island, Banc d'Arguin, Mauritania, J. Afr. Earth Sci., 50, 37-48, https://doi.org/10.1016/j.jafrearsci.2007.09.002, 2008.

Prospero, J. M. and Carlson, T. N.: Radon-222 in North Atlantic Trade Winds. Its Relationship to Dust Transport from Africa, Science, 167, 974-977, https://doi.org/10.1126/Science.167.3920.974, 1970.

Prospero, J. M. and Carlson, T. N.: Vertical and areal distribution of Saharan dust over the western equatorial north Atlantic Ocean, J. Geophys. Res., 77, 5255-5265, https://doi.org/10.1029/JC077i027p05255, 1972.

Prospero, J. M., Ginoux, P., Torres, O., Nicholson, S. E., and Gill, T. E.: Environmental characterization of global sources of atmospheric soil dust identified with the Nimbus 7 total ozone mapping spectrometer (TOMS) absorbing aerosol product, Rev. Geophys., 40, 1-31, 2002.

Pye, K.: The nature, origin and accumulation of loess, Quaternary Sci. Rev., 14, 653-667, 1995.

Radczewski, O. E.: Eolian deposits in marine sediments, in: Recent Marine Sediments, edited by: Trask, P., 496-502, Am. Assoc. Petroleum Geologists., Tulsa, 1939.

Rateev, M. A., Gorbunova, Z. N., Lisitzyn, A. P., and Nosov, G. L.: THE DISTRIBUTION OF CLAY MINERALS IN THE OCEANS, Sedimentology, 13, 21-43, https://doi.org/10.1111/j.1365-3091.1969.tb01119.x, 1969.

Ratmeyer, V., Balzer, W., Bergametti, G., Chiapello, I., Fischer, G., and Wyputta, U.: Seasonal impact of mineral dust on deepocean particle flux in the eastern subtropical Atlantic Ocean, Mar. Geol., 159, 241-252, 1999a.
Ratmeyer, V., Fischer, G., and Wefer, G.: Lithogenic particle fluxes and grain size distributions in the deep ocean off northwest Africa: Implications for seasonal changes of aeolian dust input and downward transport, Deep-Sea Res. Pt. I, 46, 1289-1337, 1999b.

Rea, D. K.: The paleoclimatic record provided by eolian deposition in the deep sea: the geologic history of wind, Rev. Geophys., 32, 159-195, 1994.

Santamarina, J. and Cho, G.: Soil behaviour: The role of particle shape, Advances in geotechnical engineering: The skempton conference, 604-617, 2004.

Scheuvens, D., Schütz, L., Kandler, K., Ebert, M., and Weinbruch, S.: Bulk composition of northern African dust and its source sediments - A compilation, Earth-Sci. Rev., 116, 170194, https://doi.org/10.1016/j.earscirev.2012.08.005, 2013.

Schlüter, T.: Geological atlas of Africa, Springer, Berlin Heidelberg, 2008.

Schofield, D., Horstwood, M., Pitfield, P., Crowley, Q., Wilkinson, A., and Sidaty, H. C. O.: Timing and kinematics of Eburnean tectonics in the central Reguibat Shield, Mauritania, J. Geol. Soc., 163, 549-560, 2006.

Schuster, M., Duringer, P., Ghienne, J.-F., Roquin, C., Sepulchre, P., Moussa, A., Lebatard, A.-E., Mackaye, H. T., Likius, A., Vignaud, P., and Brunet, M.: Chad Basin: Paleoenvironments of the Sahara since the Late Miocene, C. R. Geosci., 341, 603-611, https://doi.org/10.1016/j.crte.2009.04.001, 2009.

Schütz, L. and Sebert, M.: Mineral aerosols and source identification, J. Aerosol Sci., 18, 1-10, https://doi.org/10.1016/00218502(87)90002-4, 1987.

Selley, R. C.: Chapter 3 The sirte basin of libya, in: Sedimentary Basins of the World, edited by: Selley, R. C., Elsevier, Amsterdam, 27-37, 1997a.

Selley, R. C.: Chapter 1 The sedimentary basins of northwest africa: stratigraphy and sedimentation, in: Sedimentary Basins of the World, edited by: Selley, R. C., Elsevier, Amsterdam, 3-16, 1997b.

Selley, R. C.: Chapter 2 The basins of northwest africa: Structural evolution, in: Sedimentary Basins of the World, edited by: Selley, R. C., Elsevier, Amsterdam, 17-26, 1997c.

Shao, Y., Wyrwoll, K.-H., Chappell, A., Huang, J., Lin, Z., McTainsh, G. H., Mikami, M., Tanaka, T. Y., Wang, X., and Yoon, S.: Dust cycle: An emerging core theme in Earth system science, Aeolian Research, 2, 181-204, https://doi.org/10.1016/j.aeolia.2011.02.001, 2011.

Skonieczny, C., Bory, A., Bout-Roumazeilles, V., Abouchami, W., Galer, S. J. G., Crosta, X., Stuut, J. B., Meyer, I., Chiapello, I., Podvin, T., Chatenet, B., Diallo, A., and Ndiaye, T.: The 7-13 March 2006 major Saharan outbreak: Multiproxy characterization of mineral dust deposited on the West African margin, J. Geophys. Res., 116, D18210, https://doi.org/10.1029/2011jd016173, 2011.

Skonieczny, C., Bory, A., Bout-Roumazeilles, V., Abouchami, W., Galer, S. J. G., Crosta, X., Diallo, A., and Ndiaye, T.: A three-year time series of mineral dust deposits on the West African margin: Sedimentological and geochemical signatures and implications for interpretation of marine paleo-dust records, Earth Planet. Sc. Lett., 364, 145-156, https://doi.org/10.1016/j.epsl.2012.12.039, 2013. 
Stein, A. F., Draxler, R. R., Rolph, G. D., Stunder, B. J. B., Cohen, M. D., and Ngan, F.: NOAA's HYSPLIT Atmospheric Transport and Dispersion Modeling System, B. Am. Meteorol. Soc., 96, 2059-2077, https://doi.org/10.1175/bams-d-14-00110.1, 2015.

Stein, R.: Late neogene changes of paleoclimate and paleoproductivity off northwest africa (D.S.D.P. Site 397), Palaeogeogr. Palaeocl., 49, 47-59, https://doi.org/10.1016/00310182(85)90004-5, 1985.

Stuut, J.-B. W.: Late Quaternary Southwestern African terrestrialclimate signals in the marine record of Walvis Ridge, SE Atlantic Ocean, Faculty of Earth Sciences, Utrecht University, Utrecht, 128 pp., 2001.

Stuut, J.-B. W., Zabel, M., Ratmeyer, V., Helmke, P., Schefuß, E., Lavik, G., and Schneider, R. R.: Provenance of present-day eolian dust collected off NW Africa, J. Geophys. Res., 110, D04202, https://doi.org/10.1029/2004JD005161, 2005.

Stuut, J.-B. W., Smalley, I., and O'Hara-Dhand, K.: Aeolian dust in Europe: African sources and European deposits, Quaternary Int., 198, 234-245, https://doi.org/10.1016/j.quaint.2008.10.007, 2009.

Stuut, J.-B. W., Bakker, M., Friese, C., Koster, B., Visser, J.-D. d., and Witte, Y.: Cruise Report and preliminary results - DUSTTRAFFIC: Transatlantic fluxes of Saharan dust - Cruise No. 64PE392 - 19-27 August 2014 Las Palmas de Gran Canaria (Spain) - Mindelo, Sao Vicente (Cape Verdian Islands), 2015.

Ternon, E., Guieu, C., Loÿe-Pilot, M.-D., Leblond, N., Bosc, E., Gasser, B., Miquel, J.-C., and Martín, J.: The impact of Saharan dust on the particulate export in the water column of the North Western Mediterranean Sea, Biogeosciences, 7, 809-826, https://doi.org/10.5194/bg-7-809-2010, 2010.

Tjallingii, R., Claussen, M., Stuut, J.-B. W., Fohlmeister, J., Jahn, A., Bickert, T., Lamy, F., and Rohl, U.: Coherent high- and low-latitude control of the northwest African hydrological balance, Nature Geoscience, 1, 670-675, https://doi.org/10.1038/ngeo289, 2008.

Tsoar, H. and Pye, K.: Dust transport and the question of desert loess formation, Sedimentology, 34, 139-153, 1987.

Tucker, M. E.: Techniques in sedimentology, Blackwell Scientific Publications, Oxford, p. 394, 1988.

Van Camp, L., Nykjaer, L., Mittelstaedt, E., and Schlittenhardt, P.: Upwelling and boundary circulation off Northwest Africa as depicted by infrared and visible satellite observations, Prog. Oceanogr., 26, 357-402, https://doi.org/10.1016/00796611(91)90012-B, 1991. van der Does, M., Korte, L. F., Munday, C. I., Brummer, G.-J. A., and Stuut, J.-B. W.: Particle size traces modern Saharan dust transport and deposition across the equatorial North Atlantic, Atmos. Chem. Phys., 16, 13697-13710, https://doi.org/10.5194/acp-16-13697-2016, 2016.

Verati, C., Bertrand, H., and Féraud, G.: The farthest record of the Central Atlantic Magmatic Province into West Africa craton: Precise 40Ar/39Ar dating and geochemistry of Taoudenni basin intrusives (northern Mali), Earth Planet. Sc. Lett., 235, 391-407, https://doi.org/10.1016/j.epsl.2005.04.012, 2005.

Villeneuve, M.: Paleozoic basins in West Africa and the Mauritanide thrust belt, J. Afr. Earth Sci., 43, 166-195, https://doi.org/10.1016/j.jafrearsci.2005.07.012, 2005.

Vogt, C., Lauterjung, J., and Fischer, R. X.: Investigation of the Clay Fraction $(<2 \mu \mathrm{m})$ of the Clay Minerals Society Reference Clays, Clay. Clay Miner., 50, 388-400, 2002.

Wilson, S. and Cooke, R.: Wind erosion, in: Soil erosion, edited by: Kirkby, M. J. and Morgan, R. P. C., Wiley, Chichester, 217-251, 1980.

Wissmann, G.: Stratigraphy and structural features of the continental margin basin of Senegal and Mauritania, in: Geology of the Northwest African continental margin, Springer, Berlin Heidelberg, 160-181, 1982.

Yoshioka, M., Mahowald, N. M., Conley, A. J., Collins, W. D., Fillmore, D. W., Zender, C. S., and Coleman, D. B.: Impact of Desert Dust Radiative Forcing on Sahel Precipitation: Relative Importance of Dust Compared to Sea Surface Temperature Variations, Vegetation Changes, and Greenhouse Gas Warming, J. Climate, 20, 1445-1467, https://doi.org/10.1175/JCLI4056.1, 2007.

Yu, H. B., Chin, M., Bian, H. S., Yuan, T. L., Prospero, J. M., Omar, A. H., Remer, L. A., Winker, D. M., Yang, Y. K., Zhang, Y., and Zhang, Z. B.: Quantification of trans-Atlantic dust transport from seven-year (2007-2013) record of CALIPSO lidar measurements, Remote Sens. Environ., 159, 232-249, https://doi.org/10.1016/j.rse.2014.12.010, 2015.

Zobeck, T. M., Sterk, G., Funk, R., Rajot, J. L., Stout, J. E., and Van Pelt, R. S.: Measurement and data analysis methods for field-scale wind erosion studies and model validation, Earth Surf. Proc. Land., 28, 1163-1188, https://doi.org/10.1002/esp.1033, 2003. 